\title{
Projections of Future Changes in Precipitation and the Vertical Structure of the Frontal Zone during the Baiu Season in the Vicinity of Japan Using a 5-km-mesh Regional Climate Model
}

\author{
Sachie KANADA, Masuo NAKANO \\ Japan Agency for Marine-Earth Science and Technology, Tsukuba, Japan \\ and \\ Teruyuki KATO \\ Japan Meteorological Agency, Tokyo, Japan \\ (Manuscript received 8 March 2011, in final form 18 August 2011)
}

\begin{abstract}
Future changes in precipitation and the vertical structure of the frontal zone around Japan during the Baiu season are investigated using regional climate experiments with a 5-km-mesh non-hydrostatic model, driven for the present-day (1979-2003) and future (2075-2099) climates by output from global warming experiments using a 20-km-mesh atmospheric global circulation model under the SRES-A1B scenario.

Significant increases are projected for the future climate relative to the present-day in daily precipitation amounts around western Japan during the late Baiu season. The percentage of precipitation occurring in intense precipitation (over $100 \mathrm{~mm} \mathrm{day}^{-1}$ ) increases with statistical confidence above the $98 \%$ confidence level. In the present-day climate, $9 \%$ of the 25 -year-mean precipitation amount during early July in the region within $30^{\circ} \mathrm{N}-$ $35^{\circ} \mathrm{N}$ and $127^{\circ} \mathrm{E}-137^{\circ} \mathrm{E}$ is estimated to be dominated by intense precipitation; this value rises to $15 \%$ in the future climate.

Changes in the Baiu front and in environmental conditions around western Japan are investigated. In the future climate, a delay in the northward march of the Baiu front is projected, and the mean location of the front during the late Baiu season is $33.0^{\circ} \mathrm{N}$, compared with $33.5^{\circ} \mathrm{N}$ in the present-day. The mean amount of water vapor on the southern side of the front at a $500 \mathrm{~m}$ height increases to $19.7 \mathrm{~g} \mathrm{~kg}^{-1}$ in the future climate, an increase of $2.8 \mathrm{~g} \mathrm{~kg}^{-1}$ relative to the present-day. Mean vertical cross-sections of the front reveal tall structures of intense vertical vorticity $\left(>1.0 \times 10^{-5} \mathrm{~s}^{-1}\right)$ along an intensified frontal zone with intense mean updrafts and large amounts of rainwater in the future climate. Two of the characteristic jets associated with the Baiu front, located at a $700 \mathrm{hPa}$ level on the southern side of the front and at a $200 \mathrm{hPa}$ level on the northern side, are also intensified. The increases in the supply of water vapor and the intensified convective activity along the Baiu front could contribute to the projected increase in the occurrence of intense daily precipitation.
\end{abstract}

\section{Introduction}

Precipitation systems associated with the Asian summer monsoon, called the Baiu in Japan, are

Corresponding author: Sachie Kanada, Meteorological Research Institute, 1-1, Nagamine, Tsukuba, 305-0052, Japan.

E-mail: skanada@jamstec.go.jp

(C) 2012, Meteorological Society of Japan among the most remarkable weather phenomena in East Asia. During the Baiu season, a belt-shaped rainfall zone extends eastward along the northern boundary of the tropical maritime airmass from the southern part of the Asian Continent to the Japanese Islands. This rainfall zone corresponds climatologically to the summer monsoon front, called the Baiu front, which appears over the sea south 
of the Japanese Islands $\left(25^{\circ} \mathrm{N}-30^{\circ} \mathrm{N}\right)$ in early June and marches northward. It reaches the Korean Peninsula $\left(38^{\circ} \mathrm{N}\right)$ and rapidly weakens in late July (Ninomiya and Mizuno 1987). Based on a 30-year mean analysis, Ninomiya and Mizuno (1987) report that precipitation amounts in excess of $15 \mathrm{~mm}$ day $^{-1}$ are observed in the southern part of Kyushu from mid-June to early July. The Baiu frontal zone is often accompanied by intense precipitation over the Japanese Islands, causing severe damage to infrastructure and posing a risk to human life (Ninomiya 2000; Biao et al. 2004; Kato 2006). Future changes in the characteristics of the Baiu front and associated precipitation are of great concern to populations in East Asia.

The results of global warming projection experiments using 20-km-mesh and 60-km-mesh global atmospheric models indicate future increases of precipitation over the East China Sea and the Japanese Islands during July, and suggest that the termination of the Baiu season over Japan may be delayed until August (Kusunoki et al. 2011). When compared with observational data, however, even the super-fine hydrostatic atmospheric general circulation model with a horizontal resolution of $20 \mathrm{~km}$ (AGCM-20km) underestimate intense precipitation and overestimate the number of wet days (Kanada et al. 2010). Heavy rainfall events in East Asia are characterized by spatially and temporally concentrated events of intense precipitation (e.g., rain rate greater than $100 \mathrm{~mm} \mathrm{day}^{-1}$ ) associated with the Baiu frontal zone and typhoons (Biao et al. 2004; Kato 2006; Chen et al. 2004; Shin and Lee 2005).

The Baiu frontal zone is characterized by a narrow quasi-stationary precipitation zone, a large gradient of equivalent potential temperature, and a steady generation of convective instability (Ninomiya 1984). Intense precipitation in the frontal zone is concentrated in a narrow rainband with an east-west orientation (Ninomiya 2000). Precipitation systems associated with the Baiu frontal zone consist of several meso-scale systems of intense convective activity, with scales ranging from meso- $\alpha$ to meso- $\gamma$ (Ninomiya and Akiyama 1992). Nonhydrostatic models with horizontal resolutions on the order of several kilometers or finer are required to reproduce the structures of these convective systems and associated precipitation.

Although increases in the amount of precipitation in the vicinity of Japan during the summer rainy season do not meet the requirements for sta- tistical confidence (Intergovernmental Panel on Climate Change: IPCC 2007; Kusunoki et al. 2011), a number of previous studies using various global models have projected that the appearance frequency of intense precipitation will increase worldwide under global warming (Easterling et al. 2000; Hegerl et al. 2004; IPCC 2007; Shiogama et al. 2008; Trenberth et al. 2003). Based on a threemember ensemble experiment using the Meteorological Research Institute global ocean-atmosphere coupled general circulation model (MRI-CGCM2) under the Special Report on Emissions Scenarios (SRES) A2 and B2 scenarios, Kitoh et al. (2005) projected an increase in precipitation intensity over about one-third of the globe. Semenov and Bengtsson (2002) and Watterson and Dix (2003) reported similar projections from the results of climate change experiments using two different coupled atmosphere-ocean general circulation models (ECHARM4.OPYC3 for the period of 1900-2099 and a five-member ensemble of CSIRO Mark 2 for the period of 1871-1990 and forward to 2100 under the SRES A2 and B2 scenarios, respectively). Most such studies have analyzed global climate changes based on the results of models with relatively coarse horizontal resolutions (several tens of kilometers to approximately $100 \mathrm{~km}$ ).

Sasaki et al. (2008) revealed that a nonhydrostatic model with a horizontal resolution of $4 \mathrm{~km}$ performed well in reproducing the appearance frequency of intense precipitation. Kanada et al. (2010) compared daily precipitation amounts simulated by both a 5-km-mesh non-hydrostatic model (NHM-5km) and a 20-km-mesh atmospheric general circulation model (AGCM-20km) with daily precipitation amounts measured on a finemesh raingauge network (APHRODITE; Kamiguchi et al. 2010), and showed that NHM-5km could successfully reproduce the climatological characteristics of daily precipitation (e.g., Fig. 3 in Kanada et al. 2010). Their results show that the NHM- $5 \mathrm{~km}$ forced by output from the AGCM- $20 \mathrm{~km}$ can improve the characteristics of daily precipitation by the mother model, AGCM-20km.

In this paper, the results of regional climate change experiments using NHM-5km are investigated to study projected changes in the Baiu front and its associated precipitation during the Baiu season. The NHM- $5 \mathrm{~km}$ is forced by the output of AGCM-20km under the SRES A1B scenario. Special attention is paid to changes in the structures and environmental conditions of the front that are 
associated with intense precipitation. Previous experiments and studies have shown that the NHM$5 \mathrm{~km}$ successfully reproduces observed precipitation (Wakazuki et al. 2007; Nakamura et al. 2008; Kanada et al. 2010). Kanada et al. (2008, 2010) also demonstrated that NHM-5km is capable of reproducing the characteristics of daily precipitation, even those exceeding $100 \mathrm{~mm}$ day $^{-1}$, in the vicinity of the Japanese Islands during the warm season. The NHM-5km experiments presented here are expected to provide more reliable and more realistic projections of future changes both in precipitation and in the structure of the convective systems that bring intense precipitation in the vicinity of the Japanese Islands during the Baiu season.

\section{Model and experimental design}

Time-slice climate experiments have been performed using NHM-5km for 25-year periods representing present-day (1979-2003) and globalwarming future (2075-2099) climates as part of the Kakushin Program (Kitoh et al. 2009). NHM$5 \mathrm{~km}$ is a climate-model version of the operational numerical weather prediction model of the Japan Meteorological Agency (JMA; Saito et al. 2007), and is run from 17 May to 31 October for each year. Following a 2-week spin-up, the results from 1 June to 31 October are used for the analysis. The output intervals are 1 hour for precipitation, sea surface pressure, and surface wind speeds, and 3 hours for three-dimensional atmospheric data. NHM-5km was nested within 6-hourly output from 25-year time-integrated experiments using AGCM20km (TL959L64/MRI-AGCM3.2S; Mizuta et al. 2011b). The AGCM-20km future climate experiment was performed under the IPCC SRES A1B $\mathrm{CO}_{2}$ emissions scenarios for global warming conditions.

The NHM- $5 \mathrm{~km}$ model domain consists of $669 \times 594$ horizontal grid points covering a wide region from the eastern part of the Asian Continent to the Japanese Islands (Fig. 1). The model has 50 stretched vertical layers (depth of the lowest layer: $40 \mathrm{~m}$; top height: about $22 \mathrm{~km}$ ). A spectral nudging (SN) method, modified from the spectral boundary coupling (SBC) method (Yasunaga et al. 2005), is applied at a height above $7 \mathrm{~km}$. NHM-5km applies a cumulus parameterization scheme (Kain and Fritsch 1990) and bulk-type microphysics, including an ice phase (Murakami 1990). The cumulus parameterization scheme has been modified to sup-

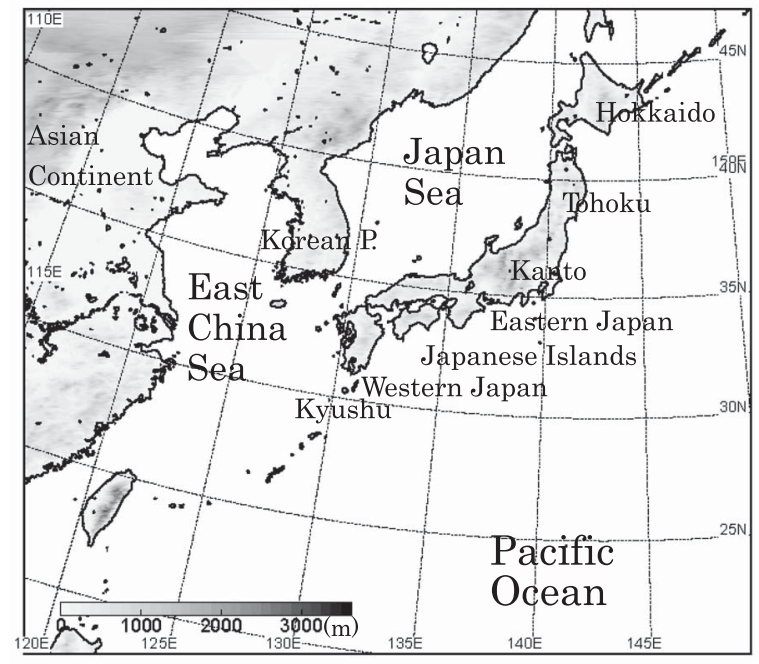

Fig. 1. Topography and domain of the NHM- $5 \mathrm{~km}$.

press false predictions of rainfall in coastal areas (Kato et al. 2010). An improved Mellor-Yamada Level 3 planetary boundary layer scheme (Nakanishi and Niino 2004) is applied. All other physical processes (e.g., radiation and surface processes) used in NHM-5km are nearly identical to those used in the JMA operational mesoscale model (Saito et al. 2007). The designs of the AGCM$20 \mathrm{~km}$ and NHM- $5 \mathrm{~km}$ experiments are described in detail by Mizuta et al. (2011b) and Kanada et al. (2010), respectively.

\section{Observational data}

The results of the present-day climate experiment (1979-2003, 25 years) are compared with rainfall analysis data obtained from Global Precipitation Climatology Project One-Degree Daily (GPCP1DD1.1), Tropical Rainfall Measuring Mission 3B43 data (TRMM3B43), and Asian Precipitation Highly Resolved Observational Data Integration Towards the Evaluation of Water Resources (APHRODITE) to examine the ability of the model to reproduce the climatology of precipitation.

i) GPCP1DD1.1 (Global Precipitation Climatology Project One-Degree Daily; 1997-2008): GPCP1DD1.1 provides daily precipitation estimates on a $1^{\circ}$ grid over the entire globe from October 1996. The data are produced by optimally merging estimates computed from micro- 
wave, infrared, and sounder data observed by the international constellation of precipitationrelated satellites, and precipitation gauge analyses (Huffman et al. 2001).

ii) TRMM3B43 (Tropical Rainfall Measuring Mission 3B43 data; 1998-2008): TRMM3B43 is derived from TRMM satellite data, which combines data from the TRMM Microwave Imager and Precipitation Radar to produce the best rain estimate. The spatial coverage of the gridded data extends from $50^{\circ} \mathrm{S}$ to $50^{\circ} \mathrm{N}$ with a spatial resolution of $0.25^{\circ}$ (Huffman et al. 2007).

iii) APHRODITE (Asian Precipitation Highly Resolved Observational Data Integration Towards the Evaluation of Water Resources Version 0902; 1979-2003): APHRODITE is a fine-mesh raingauge-based daily precipitation dataset covering the Asian region. The horizontal resolution is $0.25^{\circ}$ in longitude and latitude on land, and the dataset covers the full duration of the present-day climate experiment (19792003) (Kamiguchi et al. 2010).

\section{Definition of the summer monsoon front: The Baiu front}

Unlike traditional fronts, which are characterized by large gradients of temperature and density, the Baiu front is distinguished by large gradients of equivalent potential temperature $\left(\theta_{e}\right)$ (Ninomiya 1984, 2000). The Baiu front is therefore defined and detected in this study using the north-south gradient of $\theta_{e}$ at a height of $500 \mathrm{~m}$ at $00 \mathrm{UTC}$ on each day (Takahashi 2010). Since the Baiu front is a synoptic-scale $(>2000 \mathrm{~km})$ phenomenon, the 5$\mathrm{km}$-mesh $\theta_{e}$ data are averaged onto a $125-\mathrm{km}$-mesh throughout the NHM-5km experimental domain. Mizuta et al. (2011a) compared the results of 60$\mathrm{km}$ and 20-km models with Japanese 25-year Reanalysis data products (JRA-25: T106L40 with model top at $0.4 \mathrm{hPa}$; Onogi et al. 2007) to show that data averaged onto a $125-\mathrm{km}$-mesh adequately capture synoptic-scale phenomena. Vertical vorticities and wind shears are also estimated by wind data on a $125-\mathrm{km}-\mathrm{mesh}$. Previous studies show that the Baiu rainband extends from west to east, and that precipitation systems travel along the Baiu rainband in this direction (Ninomiya 2000; Akiyama 1989; Ninomiya and Akiyama 1992). Therefore, we focus on the portion of the Baiu front located over the sea to the west of Japan. Following Ninomiya (1984) and Kato (pers. comm.), the zone with mean values of north-south $\theta_{e}$ gradient smaller than $-0.02 \mathrm{~K} \mathrm{~km}^{-1}$ is defined as 'the frontal zone', the minimum value of the northsouth $\theta_{e}$ gradient is defined as 'the intensity of the front', and the location of the frontal zone is defined as 'the location of front'. According to Ninomiya and Mizuno (1987), the Baiu front extends along the northern boundary of the tropical maritime airmass. The climatological location of the Baiu front roughly corresponds to that of $\theta_{e}=$ $340 \mathrm{~K}$ at a height of $850 \mathrm{hPa}$. In the present climate, the meridional location of the 25-year mean $\theta_{e}$ of $340 \mathrm{~K}$ at a height of $850 \mathrm{hPa}$ corresponds well to the mean location of the front detected using the gradient-based method described above.

\section{Results}

\subsection{General characteristics of simulated Baiu precipitation}

The 25-year climatology of monthly mean precipitation amounts simulated by NHM- $5 \mathrm{~km}$ in June and July for the present-day (1979-2003) is compared with that simulated by AGCM-20km and those observed by GPCP1DD1.1 (1997-2008), TRMM3B43 (1998-2007), and APHRODITE (1979-2003) (Figs. 2 and 3). Also included are monthly mean precipitation climatologies simulated for the future climate (2075-2099) by AGCM-20km and NHM-5km, and changes from the present-day climatology projected by both models. Note that the available periods of GPCP and TRMM (12 and 10 years, respectively) are shorter than 25 years. In June, precipitation bands extend from the southern part of the East China Sea to the Japanese Islands in the present climatology (Fig. 2a and 2b). Mean precipitation amounts are larger in western Japan than in eastern Japan. Precipitation amounts exceed $6 \mathrm{~mm} \mathrm{day}^{-1}$ in land regions of the Japanese Islands south of $36^{\circ} \mathrm{N}$ and west of $140^{\circ} \mathrm{E}$, and exceed $12 \mathrm{~mm}$ day $^{-1}$ over Kyushu (location in Fig. 1). Precipitation amounts that exceed $8 \mathrm{~mm}$ day $^{-1}$ are observed in the region within $137^{\circ} \mathrm{E}-139^{\circ} \mathrm{E}$ and $35^{\circ} \mathrm{N}-37^{\circ} \mathrm{N}$ by APHRODITE, but are not captured by GPCP or TRMM. AGCM-20km (Fig. 2d) is able to reproduce the present-day climatological distribution of mean precipitation amounts, although values are underestimated over the western part of the East China Sea. The horizontal pattern of monthly precipitation amounts simulated by NHM-5km is largely similar to that simulated by AGCM-20km, though NHM- $5 \mathrm{~km}$ suppresses the intense grid-scale precip- 


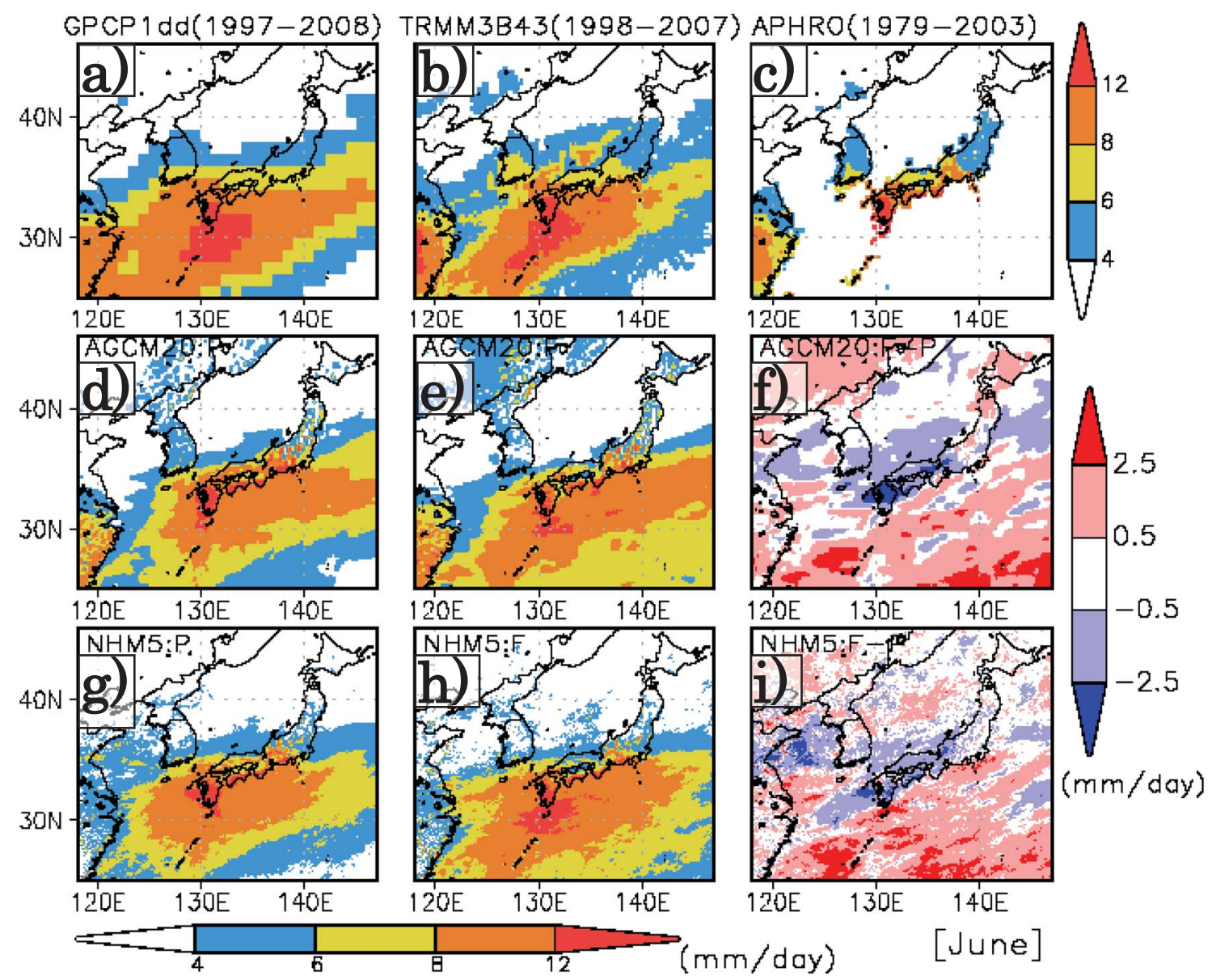

Fig. 2. Horizontal distributions of mean monthly precipitation amounts in June (mm day ${ }^{-1}$ ): a) GPCP1dd1.1 (1997-2008), b) TRMM3B43 (1998-2007), c) APHRODITE (1979-2003), d) AGCM-20km (1979-2003), e) AGCM-20km (2075-2099), f) future change projected by AGCM-20km, g) NHM-5km (1979-2003), h) NHM-5km (2075-2099), and i) future change projected by NHM-5km.

itation simulated in the Kanto and Tohoku districts by AGCM-20km. There is no remarkable precipitation over the Asian Continent near the lateral boundary of the NHM- $5 \mathrm{~km}$ model domain. Precipitation tends to be underestimated by NHM$5 \mathrm{~km}$ near the model boundary on the upwind side because water substances are not nested from the outer model to the inner model. In the future climate, a band-shaped precipitation area is found over the sea south of the Japanese Islands (Fig. 2e and $2 \mathrm{~h}$ ). Precipitation amounts are projected to decrease over most regions of the Japanese Islands, with the exception of Hokkaido (Fig. $2 \mathrm{f}$ and 2i). This projection is consistent with the results of $\mathrm{Ku}-$ sunoki et al. (2011), who reported that the northward march of the Baiu front in East Asia may be delayed in the future climate.
The band-shaped precipitation area shifts northward in July. Regions of precipitation amounts that exceed $8 \mathrm{~mm}$ day $^{-1}$ are observed over Kyushu Island and on the western side of the Korean Peninsula (Fig. 3a-3c). As in June, precipitation amounts in excess of $8 \mathrm{~mm}$ day $^{-1}$ that are observed by APHRODITE in the region $137^{\circ} \mathrm{E}-139^{\circ} \mathrm{E}$ and $35^{\circ} \mathrm{N}-$ $37^{\circ} \mathrm{N}$ are not found in the GPCP or TRMM data. The present-day AGCM-20km and NHM-5km simulations roughly reproduce the climatological distribution of precipitation amounts (Fig. 3d and $3 \mathrm{~g}$ ). In the future climate, precipitation amounts are projected to decrease in most areas of the Japanese Islands and are projected to increase over the sea to the south of Japan, although these differences are not statistically significant (Fig. $3 \mathrm{f}$ and 3i). 


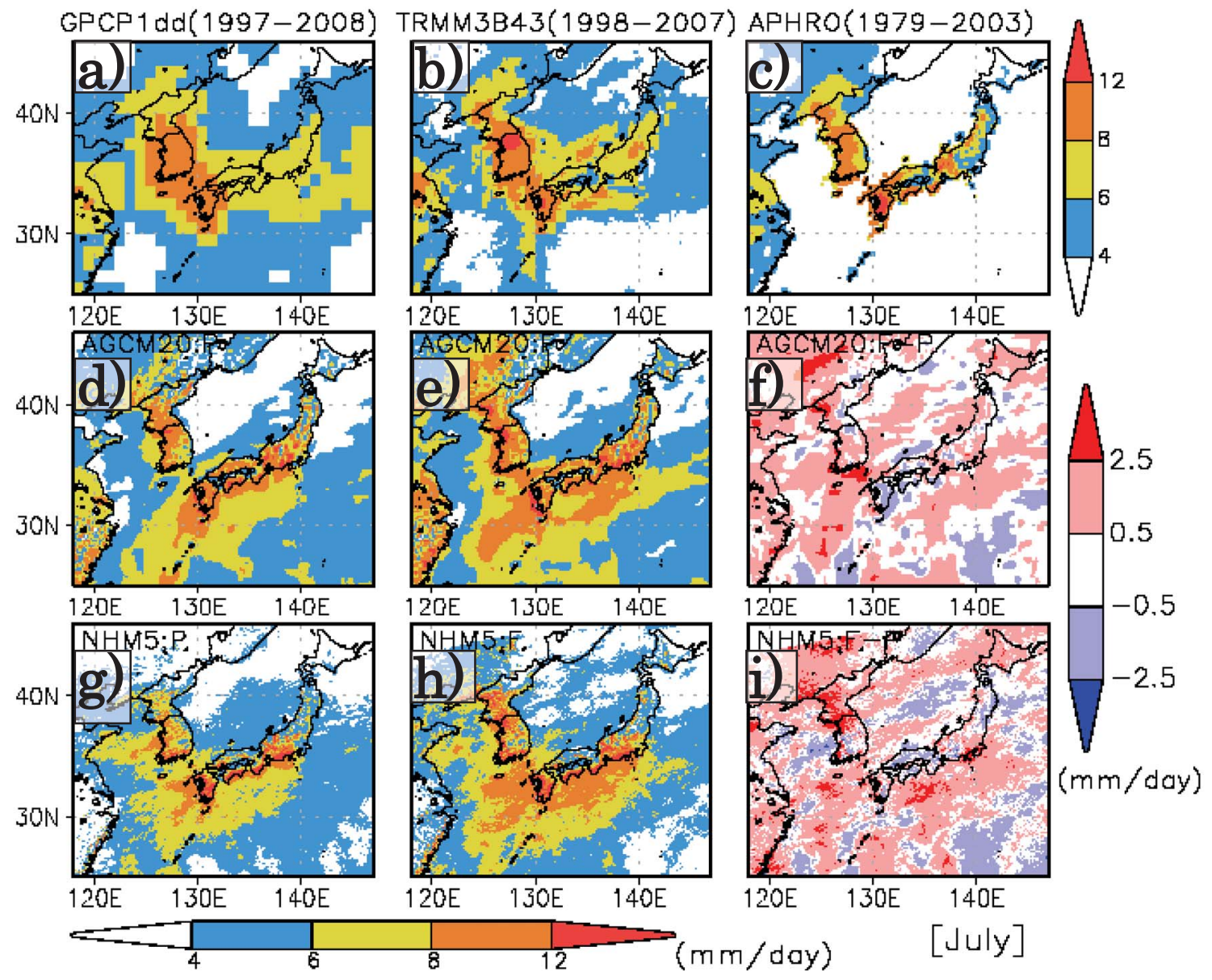

Fig. 3. Same as Fig. 2, but for mean monthly precipitation amounts in July.

The seasonal variation of the Baiu front (i.e., its northward march) is one of its most important characteristics. Seasonal variations of daily precipitation from June to September around western Japan $\left(30^{\circ} \mathrm{N}-35^{\circ} \mathrm{N}\right)$ are shown in Fig. 4. First, the variations of the present-day climate simulated by NHM-5km are compared with those of GPCP. GPCP show that precipitation areas associated with the Baiu front shift northward from $25^{\circ} \mathrm{N}-$ $30^{\circ} \mathrm{N}$ in early June to $35^{\circ} \mathrm{N}$ in late July, at which point the intensity of the precipitation rapidly weakens (Fig. 4a). The climatological conditions over western Japan are predominantly hot and dry from late July through August. In late August, major precipitation areas begin to march southward from the north of Japan. September and October represent a typhoon season in the vicinity of the Japanese Islands. The seasonal variations of precipitation amounts simulated for the present-day cli- mate by NHM-5km are nearly coincident with those of GPCP, although the northward march of precipitation areas is moderated slightly. In the future climate, regions between $25^{\circ} \mathrm{N}$ and $35^{\circ} \mathrm{N}$ are widely characterized by precipitation amounts that exceed $8 \mathrm{~mm} \mathrm{day}^{-1}$ from mid-June to mid-July. Precipitation is projected to be light in regions north of $35^{\circ} \mathrm{N}$, especially in June. The delay of the northward march of the Baiu front in the future climate is signaled by a dipole of projected changes in precipitation amounts during the period between mid-June and mid-July: precipitation is projected to decrease over western Japan $\left(30^{\circ} \mathrm{N}-35^{\circ} \mathrm{N}\right)$ and increase over the sea south of the Japanese Islands $\left(25^{\circ} \mathrm{N}-30^{\circ} \mathrm{N}\right)$ from mid-June to late June (Fig. $4 \mathrm{~d}$ ). In late June, remarkable increases in precipitation amounts of over $2.5 \mathrm{~mm} \mathrm{day}{ }^{-1}$ are widely found in maritime regions south of $30^{\circ} \mathrm{N}$, and extend over western Japan in early July. Precipitation amounts 


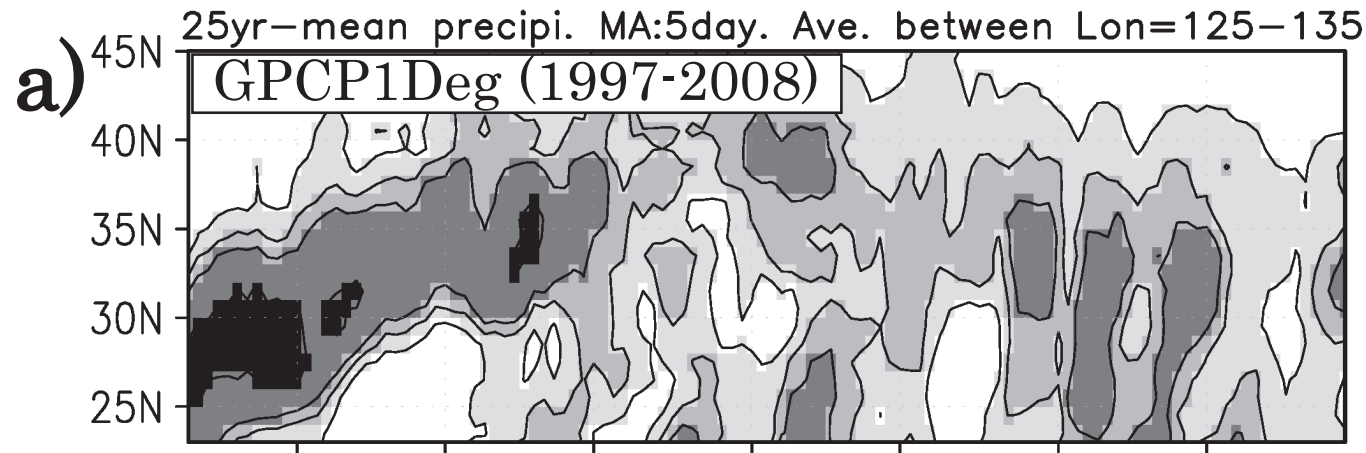

b)

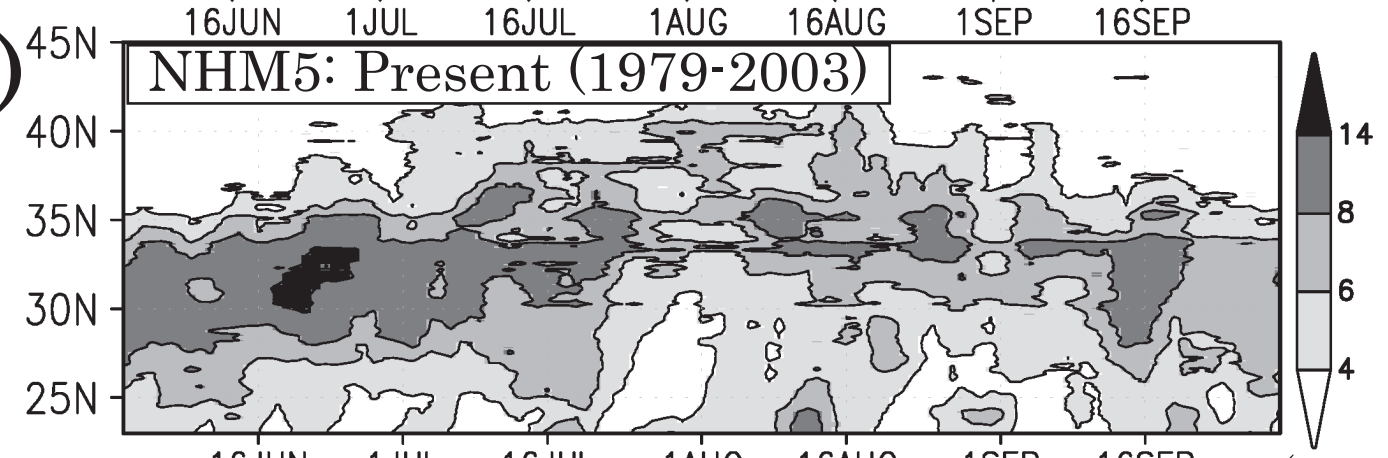

c)
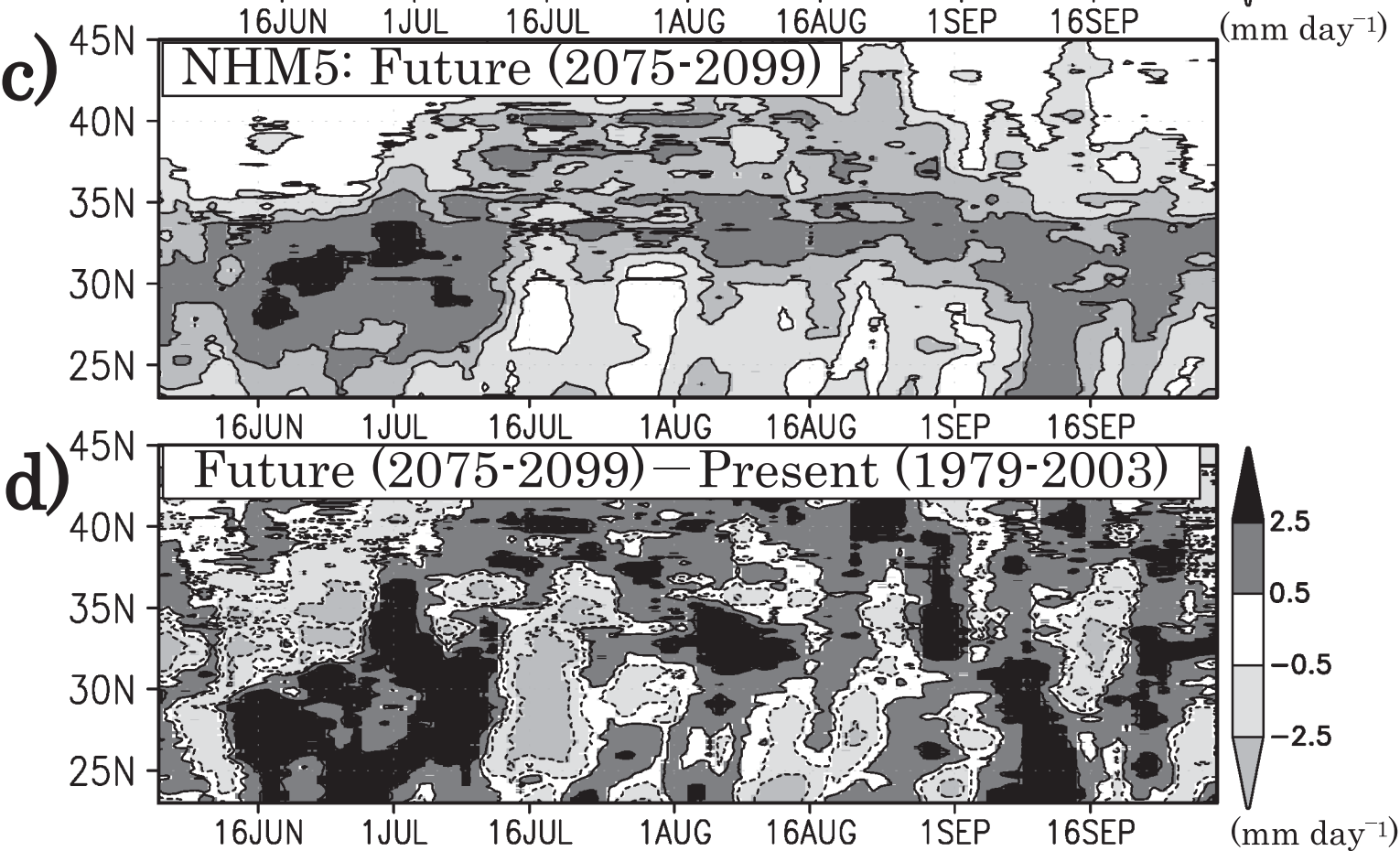

Fig. 4. Seasonal variations of daily precipitation amounts $(\mathrm{mm})$ between $24^{\circ} \mathrm{N}$ and $45^{\circ} \mathrm{N}$, averaged over $125^{\circ} \mathrm{E}$ to $135^{\circ} \mathrm{E}$ : a) GPCP1dd1.1 (1997-2008), b) NHM-5km (1979-2003), c) NHM-5km (2075-2099), and d) future changes projected by NHM- $5 \mathrm{~km}$. 
also increase by more than $2.5 \mathrm{~mm} \mathrm{day}^{-1}$ in western Japan during early August.

Seasonal variations of simulated daily precipitation amounts over western Japan $\left(127^{\circ} \mathrm{E}-137^{\circ} \mathrm{E}\right.$, $30^{\circ} \mathrm{N}-35^{\circ} \mathrm{N}$ ) are shown in Fig. 5a. The 25-year climatological mean daily precipitation amounts simulated for the present-day climate by NHM$5 \mathrm{~km}$ (thin line with white squares in Fig. 5a) coincide well with analyzed precipitation amounts from radar-raingauge observations (long, thick dashed line), including the timing of the peak precipitation in late June. These results show that NHM-
$5 \mathrm{~km}$ successfully represents the mean daily precipitation amounts. In the future climate, significant increases in precipitation amounts are detected in early July and early August. These increases exceed the $90 \%$ confidence level (Welch's t-test) between 30 June and 10 July and between 31 July and $10 \mathrm{Au}-$ gust.

According to Kanada et al. (2010), NHM-5km can reproduce the characteristics of daily precipitation even for intense precipitation. Figure $5 \mathrm{~b}$ shows seasonal variations in the fraction of amounts of intense precipitation (above $100 \mathrm{~mm} \mathrm{day}^{-1}$ ) to total
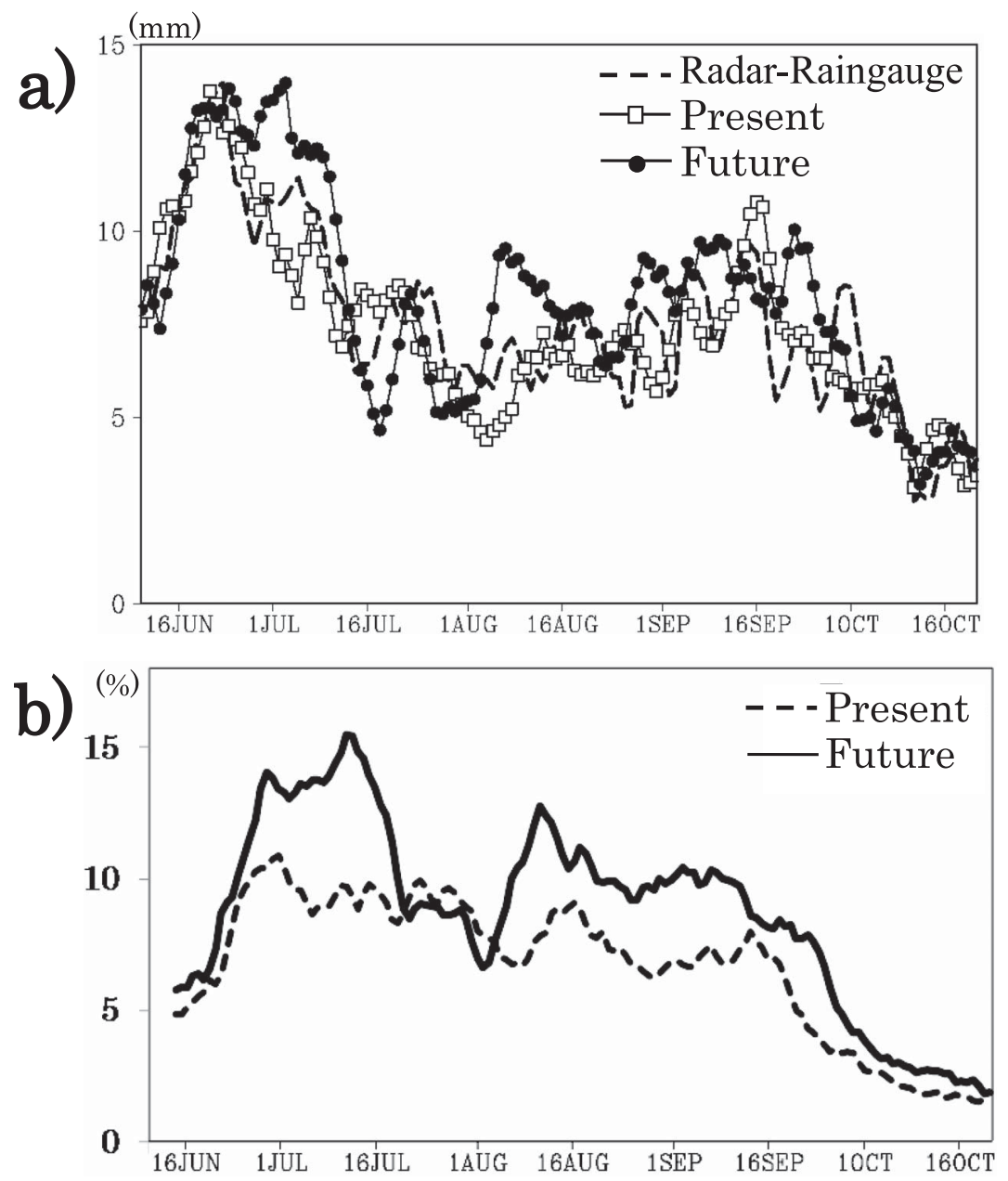

Fig. 5. a) Seasonal variations of 25-year mean daily precipitation amounts ( $\mathrm{mm}$ ) averaged within the domain $127^{\circ} \mathrm{E}-137^{\circ} \mathrm{E}$ and $30^{\circ} \mathrm{N}-35^{\circ} \mathrm{N}$, as observed by Radar-Raingauge analyzed precipitation (1996-2009, dashed line) and simulated for the present-day (1979-2003, open square) and future (2075-2099, black circle) climates by NHM-5km. b) Seasonal variations in the fraction of amounts of intense precipitation (above $100 \mathrm{~mm} \mathrm{day}^{-1}$ ) to total amounts, averaged within the same domain, as simulated for the presentday (1979-2003, dashed line) and future (2075-2099, thick solid line) climates by NHM-5km. All data represent 5-day moving averages. 
amounts. Increases in this fraction are detected throughout almost the entire simulated period, with particularly remarkable increases detected between 29 June and 8 July (statistical confidence above the $98 \%$ confidence level, Welch's t-test). In the present-day climate experiment, $9 \%$ of the precipitation amounts in early July in western Japan $\left(30^{\circ} \mathrm{N}-35^{\circ} \mathrm{N}, 127^{\circ} \mathrm{E}-137^{\circ} \mathrm{E}\right)$ occurs in intense precipitations exceeding $100 \mathrm{~mm} \mathrm{day}^{-1}$; this fraction rises to $15 \%$ in the future climate.

\subsection{Changes in the general characteristics of the simulated Baiu front}

The results presented in the previous subsection reveal that precipitation amounts in western Japan are projected to increase substantially in early July in the future climate. The fraction of precipitation occurring in intense precipitation (above $100 \mathrm{~mm} \mathrm{day}^{-1}$ ) also increases during the period. Early July corresponds to the late Baiu season in western Japan, and most of the precipitation in this period occurs in the Baiu frontal zone. The following discussion therefore focuses on changes in the characteristics of the Baiu front during the Baiu season.

Figure 6 shows the horizontal distributions of precipitation amounts and mean sea level pressures in the present-day and future climates broken down into 10-day mean amounts between 11 June and 10 August. In the present-day climate, precipitation areas extend from west to east over the southern part of western Japan during mid-June (Fig. 6a). These precipitation areas gradually shift northward from mid-June to mid-July, as the North Pacific subtropical anticyclone moves northward. Precipitation intensity weakens in late July. In early August, when the subtropical anticyclone extends over Japan, precipitation over the Japanese Islands is very light (Fig. 6f), and Japan experiences hot and dry summer days.

In the future climate, the northward march of precipitation areas is delayed as the subtropical anticyclone remains over the southern ocean. Large amounts of precipitation still occur over the southern sea in mid-June. Regions of large mean precipitation (greater than $12 \mathrm{~mm} \mathrm{day}^{-1}$ ) are found around western Japan from late June through early July. Precipitation over the Japanese Islands rapidly weakens as the subtropical anticyclone is elongated westward. In early August, the subtropical anticyclone retreats to the south while maintaining its westward protrusion. The pressure pattern that accompanies this retreat is similar to that observed in the late Baiu season in the present-day climate. Regions of mean precipitation amounts that exceed $9 \mathrm{~mm} \mathrm{day}^{-1}$ occur along the northwestern periph-

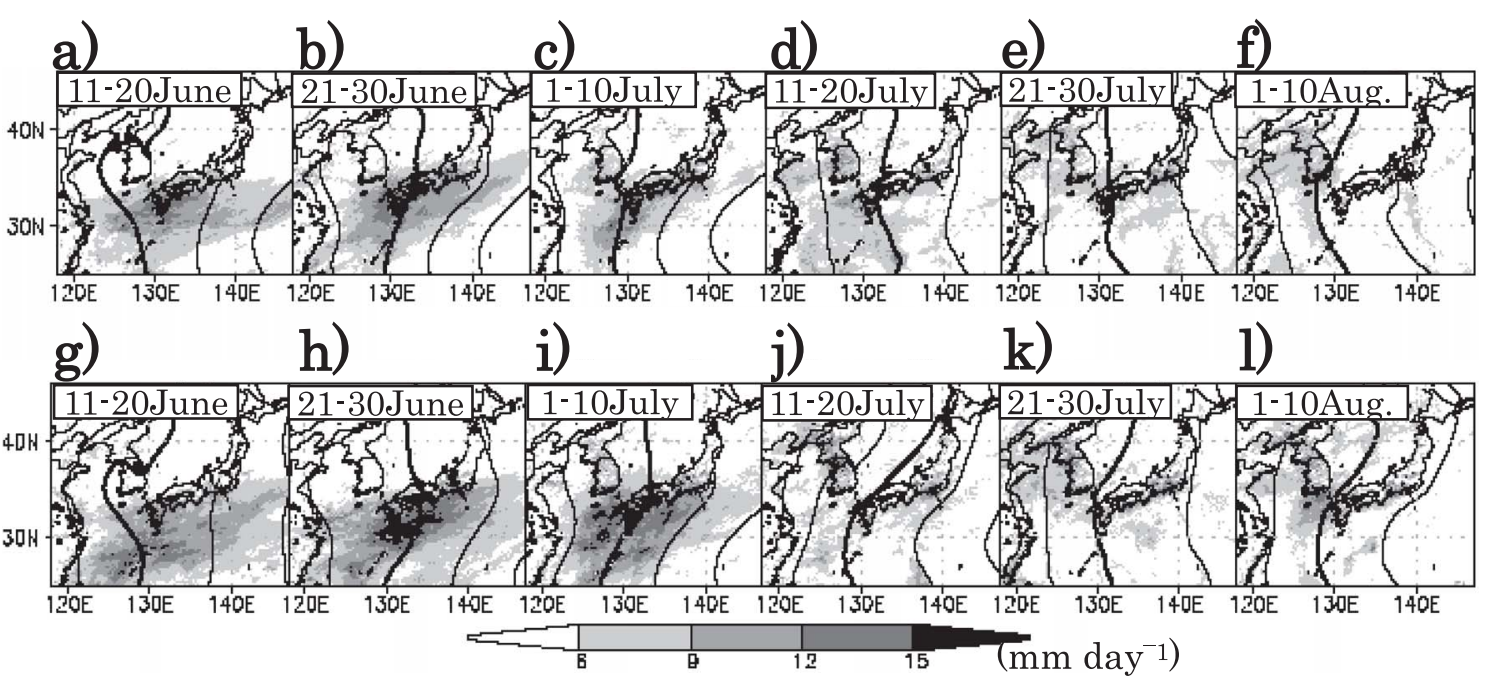

Fig. 6. Horizontal distributions of mean precipitation $\left(\mathrm{mm} \mathrm{day}^{-1}\right)$ and sea level pressure $(\mathrm{hPa})$ for the periods a) 11-20 June, b) 21-30 June, c) 1-10 July, d) 11-20 July, e) 21-30 July, and f) 1-10 August averaged over 25 years of the present-day climate experiments (1979-2003). g)-1): Same as a)-f) but averaged over 25 years of the future climate experiments (2075-2099). Thick contours indicate mean sea level pressure of $1008 \mathrm{hPa}$. Contour interval is $2 \mathrm{hPa}$. 
ery of the westward-protruding subtropical anticyclone, in the vicinity of Kyushu.

As shown in Fig. 3, there is no significant change projected for monthly precipitation during July in the vicinity of the Japanese Islands; however, precipitation amounts are projected to increase significantly in western Japan in early July, during the late Baiu season (Figs. 5 and 6). The following section therefore focuses on the 10-day mean variability of the Baiu front.

The location of the Baiu front (defined as the locations of the strongest 10-day mean north-south gradients of $\theta_{e}$ at a height of $500 \mathrm{~m}$ between $125^{\circ} \mathrm{E}$ and $130^{\circ} \mathrm{E}$ ) is approximately $32^{\circ} \mathrm{N}$ in late June in the present-day and future climates (Fig. 7). The gradients weaken as the locations of the minima shift northward, especially in the present-day climate. The weakening of the gradients is less pronounced in the future climate, in which the gradients are still approximately $-0.03 \mathrm{~K} \mathrm{~km}^{-1}$ even in early July. Because these characteristics are detected from simple averages of the north-south $\theta_{e}$ gradients, they do not directly indicate the intensity or location of the Baiu front. Comparing the

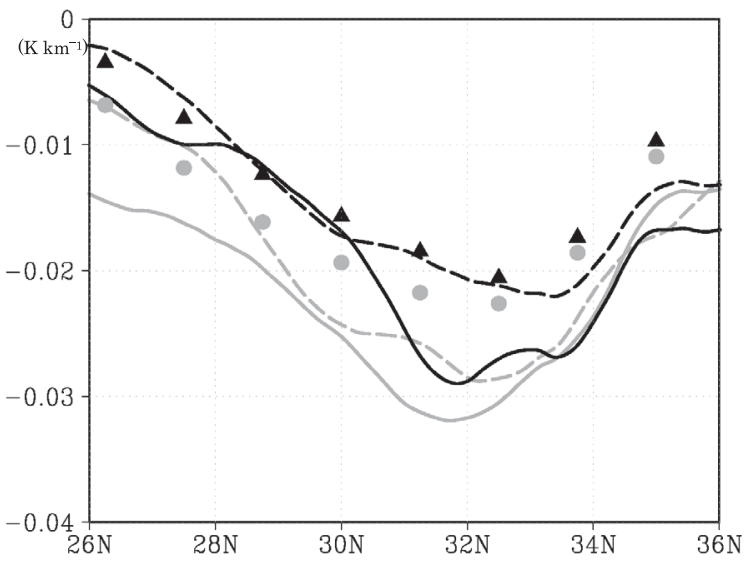

Fig. 7. Ten-day mean north-south gradients of equivalent potential temperature $\left(\mathrm{K} \mathrm{km}^{-1}\right.$ ) averaged between $125^{\circ} \mathrm{E}$ and $130^{\circ} \mathrm{E}$ during 21-30 June (grey dashed: present-day, grey solid: future) and 1-10 July (thick dashed: present-day, thick solid: future). Climatological distributions of 10-day mean north-south gradients of equivalent potential temperature $\left(\mathrm{K} \mathrm{km}^{-1}\right)$ averaged between $125^{\circ} \mathrm{E}$ and $130^{\circ} \mathrm{E}$ by JRA-25 reanalysis data are included for 21-30 June (grey circles) and 1-10 July (black triangles). present-day climate simulations with JRA-25, both the locations and intensities of the Baiu front are consistent.

Using the detection method introduced in the previous subsection, the general characteristics of the Baiu front over the sea west of Kyushu (between $125^{\circ} \mathrm{E}$ and $130^{\circ} \mathrm{E}$ ) from 11 June to $20 \mathrm{July}$ are investigated for each 1-degree latitude bin (Fig. 8). For example, the frequency for $32^{\circ} \mathrm{N}$ indicates the average fraction of days on which the front is between $32^{\circ} \mathrm{N}$ and $33^{\circ} \mathrm{N}$, and the intensity for $32^{\circ} \mathrm{N}$ indicates the mean value of north-south gradients of $\theta_{e}$ associated with the front when it is located between $32^{\circ} \mathrm{N}$ and $33^{\circ} \mathrm{N}$. In the present-

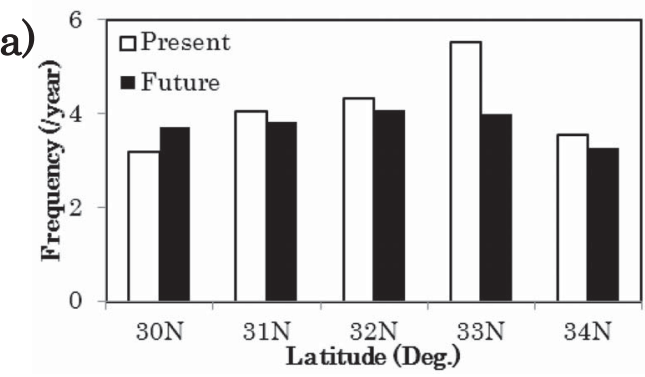

b)

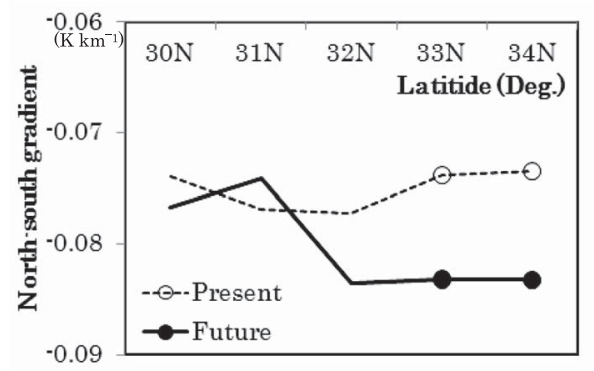

Fig. 8. a) Frequency (year ${ }^{-1}$ ) and b) mean intensity $\left(\mathrm{K} \mathrm{km}^{-1}\right)$ of the Baiu front between $125^{\circ} \mathrm{E}$ and $130^{\circ} \mathrm{E}$ from 11 June to 20 July for each $1^{\circ}$ latitude bin. The intensity of the Baiu front is estimated from the absolute maximum north-south gradient of equivalent potential temperature. For example, a frequency for $32^{\circ} \mathrm{N}$ indicates the number of days per year that the front is located between $32^{\circ} \mathrm{N}$ and $33^{\circ} \mathrm{N}$ and an intensity for $32^{\circ} \mathrm{N}$ indicates the mean intensity of the front when it is located between $32^{\circ} \mathrm{N}$ and $33^{\circ} \mathrm{N}$. Open and black circles indicate that the statistical confidence for the difference between the mean intensity in the present-day climate and the mean intensity in the future climate exceeds the $90 \%$ confidence level. 
day climate, the highest frequency is found at $33^{\circ} \mathrm{N}$; this location corresponds to the sea west of Kyushu. In the future climate, the differences between latitudes are small and the highest frequency is found at $32^{\circ} \mathrm{N}$. The intensity of the front when it is located north of $32^{\circ} \mathrm{N}$ is projected to change substantially. The mean intensity of the front south of $32^{\circ} \mathrm{N}$ is approximately $-0.078 \mathrm{~K} \mathrm{~km}^{-1}$ in both climates (Fig. 8b); however, the mean intensity for the front on the north side of $32^{\circ} \mathrm{N}$ increases from $-0.073 \mathrm{~K} \mathrm{~km}^{-1}$ in the present-day climate to $-0.083 \mathrm{~K} \mathrm{~km}^{-1}$ in the future climate. The statistical confidence for this increase exceeds the $93 \%$ confidence level at $33^{\circ} \mathrm{N}$ and $34^{\circ} \mathrm{N}$.

The results shown in Fig. 8 represent the mean characteristics of the Baiu front over a time period of more than 1 month. As mentioned in the previous subsection, a higher temporal resolution is required to study phenomena that have intraseasonal variations (such as the Baiu front). The characteristics of the front are therefore presented for each 10-day period between mid-June and early August (Fig. 9). Large square marks indicate differences between the present-day and future climates meet the statistical confidence above the 90\% confidence level. In late June (21-30 June), the mean locations of the Baiu front are found to be at $32.7^{\circ} \mathrm{N}$ and $31.6^{\circ} \mathrm{N}$ in the present-day and future climates, respectively, with intensities (minimum north-south $\theta_{e}$ gradients) of $-0.076 \mathrm{~K} \mathrm{~km}^{-1}$ and $-0.082 \mathrm{~K} \mathrm{~km}^{-1}$. In early July, the mean locations of the front are detected to be at $33.5^{\circ} \mathrm{N}$ and $33.0^{\circ} \mathrm{N}$ with intensities of $-0.065 \mathrm{~K} \mathrm{~km}^{-1}$ and $-0.073 \mathrm{~K} \mathrm{~km}^{-1}$, respectively. The locations of the front in the present-day climate experiment are largely consistent with those reported by Ninomiya and Akiyama (1992, their Fig. 3). Statistically significant differences between the present-day and future climates are identified in the delay of the northward march of the front from late June to early July, and in the increases of the intensity of the front in mid-June, early July, and mid-July. The intensity of the front in the present-day climate is weaker than $-0.07 \mathrm{~K} \mathrm{~km}^{-1}$ after early July. This weakening is more moderate in the future climate, in which the intensity remains greater than $-0.07 \mathrm{~K} \mathrm{~km}^{-1}$ until mid-July.

\subsection{Changes of the Baiu front in the late Baiu season}

These changes in the general characteristics of the Baiu front, summarized in the previous subsec-
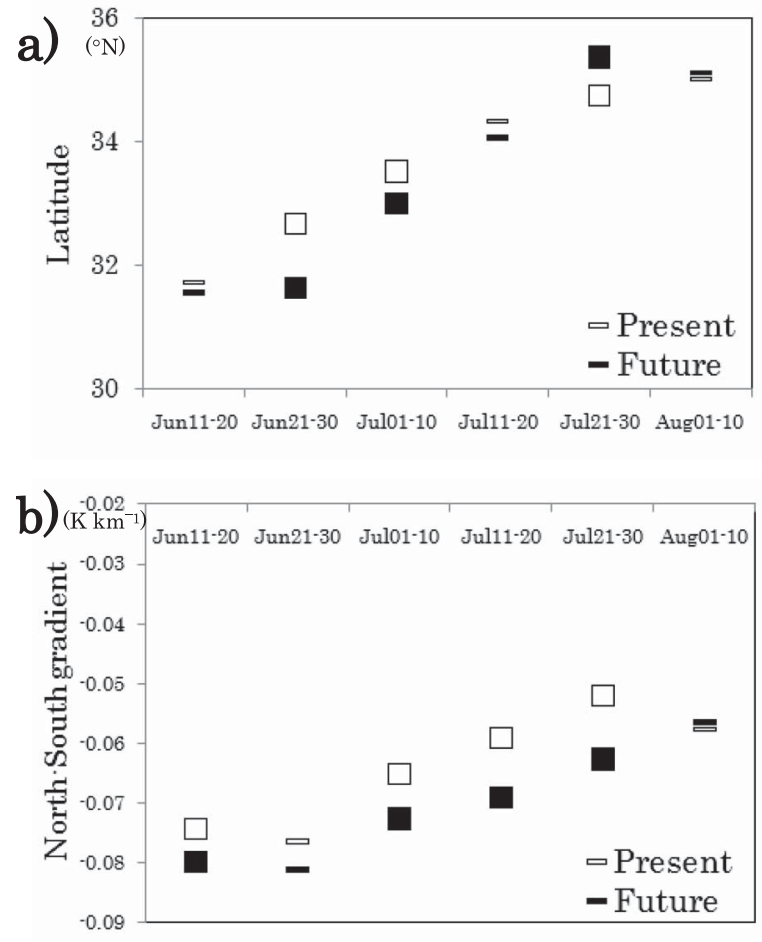

Fig. 9. a) Mean location and b) intensity of the Baiu front between $125^{\circ} \mathrm{E}$ and $130^{\circ} \mathrm{E}$ for each 10-day period between 11 June to 10 August in the present-day (open square) and future (black square) climates. The intensity is estimated from the absolute maximum of the north-south gradient of equivalent potential temperature. Large square marks indicate that the statistical confidence for the difference between the present-day and future climates exceeds the $90 \%$ confidence level.

tion, may effect changes in the amounts and characteristics of precipitation. This subsection focuses on changes in the Baiu front and its associated precipitation during the late Baiu season, when substantial increases in precipitation are projected. Special attention is paid to the relationship between changes in the Baiu front and the increases in intense precipitation projected for the region between $30^{\circ} \mathrm{N}$ and $35^{\circ} \mathrm{N}$. Data on days for which a typhoon is detected in the region bounded by $25^{\circ} \mathrm{N}-40^{\circ} \mathrm{N}$ and $120^{\circ} \mathrm{E}-140^{\circ} \mathrm{E}$ (TC-days) are excluded, and only data on days that the Baiu front is located between $30^{\circ} \mathrm{N}$ and $35^{\circ} \mathrm{N}$ (front-detected days) are used. The total number of days that meet these criteria is 109 in the present-day climate and 128 in the future climate. The horizontal distributions of 


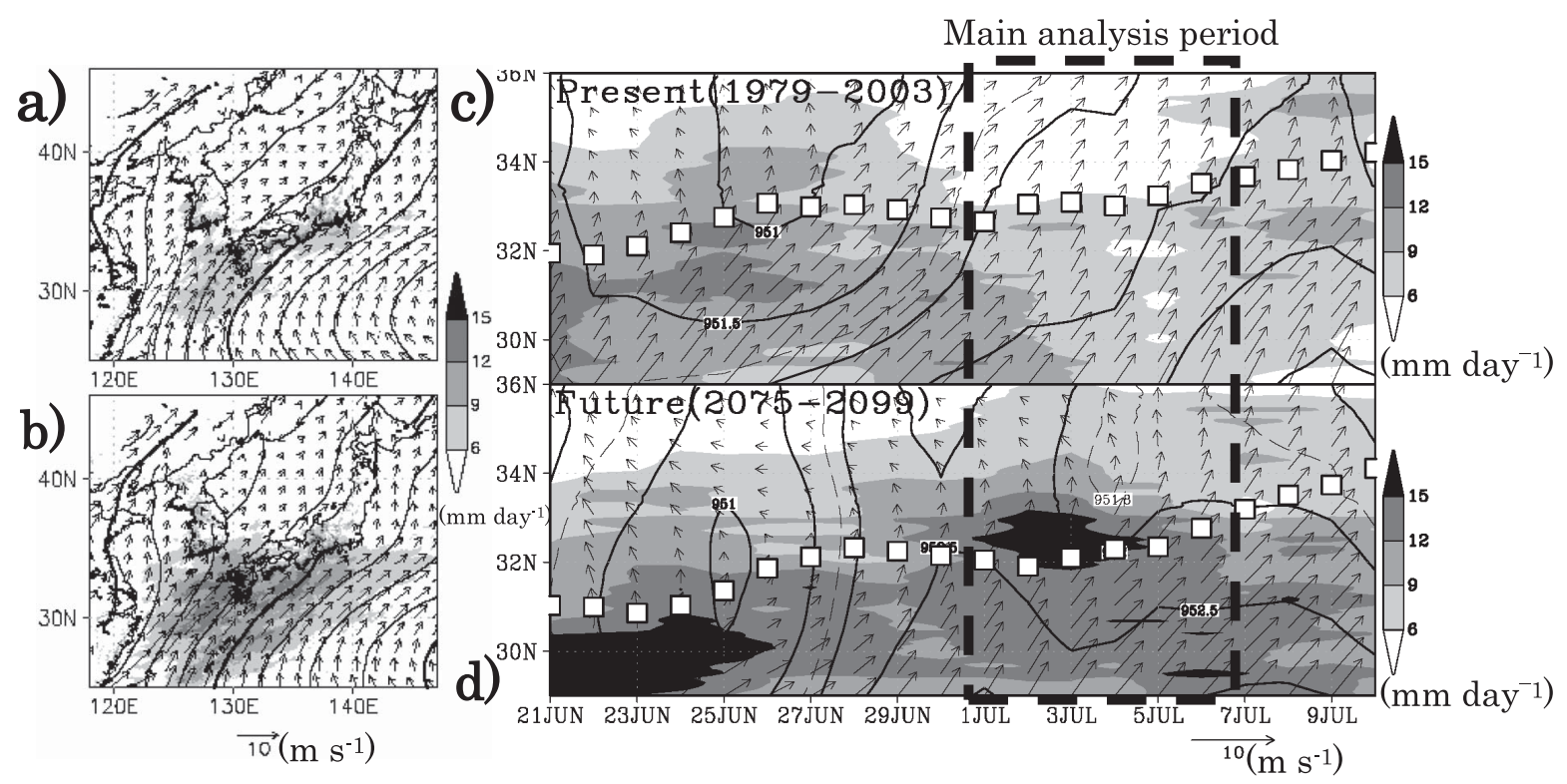

Fig. 10. Horizontal distributions of mean precipitation amounts (shaded: $m m$ day $^{-1}$ ), sea level pressure (contour: $\mathrm{hPa}$ ), and horizontal winds at a height of $10 \mathrm{~m}$ (vector; $\mathrm{m} \mathrm{s}^{-1}$ ) between 1 and $10 \mathrm{July}$ a) in the presentday climate and b) in the future climate. Thick contours indicate $1008 \mathrm{hPa}$. Contour interval is $2 \mathrm{hPa}$. Time-latitude cross-sections of mean precipitation (shaded: $\mathrm{mm} \mathrm{day}^{-1}$ ), pressure (contour: $\mathrm{hPa}$ ), and horizontal winds (vector; $\mathrm{m} \mathrm{s}^{-1}$ ) at a height of $500 \mathrm{~m} \mathrm{c}$ ) in the present-day climate and $\mathrm{d}$ ) in the future climate averaged between $125^{\circ} \mathrm{E}$ and $130^{\circ} \mathrm{E}$ and between 21 June and $10 \mathrm{July}$. The mean positions of the Baiu front are shown by white boxes. Days for which typhoons are detected in the NHM-5km model domain are excluded from both analyses.

mean precipitation associated with the Baiu front in early July are shown in Fig. 10a and 10b, along with the distributions of mean sea level pressure and horizontal winds at a height of $10 \mathrm{~m}$. Along with Fig. 6c, Fig. 10 shows that TC-related precipitation represents a larger proportion of the total precipitation in early July in the present-day climate than in the future climate. Western Japan is projected to experience large amounts of precipitation in the future climate even without TC-days. In the future climate, the subtropical anticyclone is located over the southern ocean and extends westward at approximately $25^{\circ} \mathrm{N}$. Intense southwesterly winds prevail over the sea south of the Japanese Islands, along the northwestern periphery of the westward-protruding subtropical anticyclone. A cyclonic circulation is found over the sea northwest of Kyushu $\left(127^{\circ} \mathrm{E}, 34^{\circ} \mathrm{N}\right)$. The time-latitude crosssection of 25-year mean daily precipitation between $125^{\circ} \mathrm{E}$ and $130^{\circ} \mathrm{E}$ reveals that precipitation along the mean location of the front during early July exceeds $15 \mathrm{~mm} \mathrm{day}^{-1}$ in the future climate (Fig. 10d). Strong south-westerly winds prevail on the south- ern side of the front, and regions of relatively low pressure and cyclonic circulation are found over the sea northwest of Kyushu $\left(34^{\circ} \mathrm{N}\right)$, on the northern side of the front. The strong south-westerly winds identified on the southern side of the front are also found in the present-day climate during late June, but weaken by early July. To study mean structures of the front associated with the projected increase of intense precipitation in early July, all of the data on front-detected days during the period when intense precipitations (greater than $12 \mathrm{~mm} \mathrm{day}{ }^{-1}$ ) are found in the vicinity of the front ('main analysis period' shown in Fig. 10) are composited according to front location.

Figure 11 shows mean vertical cross-sections of the front between 1 July and 7 July. All data are composited according to the position of the strongest north-south $\theta_{e}$ gradient at a height of $500 \mathrm{~m}$. As above, data from TC-days are excluded and only data from front-detected days are included. Convectively unstable layers can be found in the cross-section on the southern side of the Baiu front axis $(x=0 \mathrm{~km})$ in both climates. The 


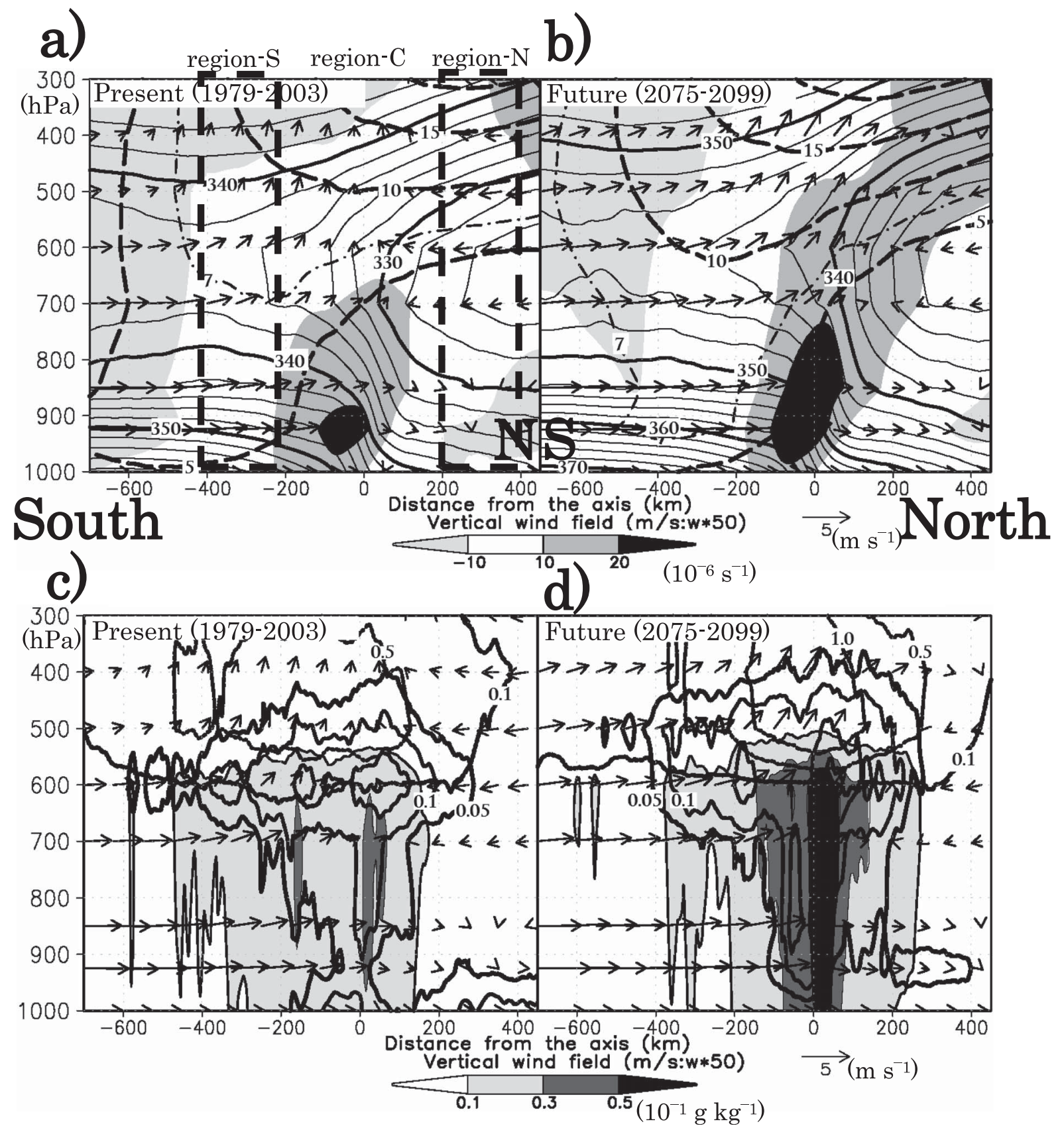

Fig. 11. North-south cross-sections of 25-year mean vertical vorticity (shaded: $10^{-6} \mathrm{~s}^{-1}$ ), equivalent potential temperature (contour: K), wind speeds (dashed line: $\mathrm{m} \mathrm{s}^{-1}$ ), and wind fields in the sections of the Baiu front detected in the region bounded by $30^{\circ} \mathrm{N}-35^{\circ} \mathrm{N}$ and $125^{\circ} \mathrm{E}-130^{\circ} \mathrm{E}$ between 1 and 7 July in a) the present-day climate and b) the future climate. All data are composited with the Baiu front axis defined by the position of the largest north-south gradient of equivalent potential temperature at a height of $500 \mathrm{~m}$. As in Fig. 11a and b, but for mixing ratios of rainwater (shaded: $10^{-1} \mathrm{~g} \mathrm{~kg}^{-1}$ ), cloudwater (thick solid: $0.05,0.1$, 0.2, 0.3: $10^{-1} \mathrm{~g} \mathrm{~kg}^{-1}$ ), snow (thin solid: 0.1, 0.5, 1.0: $10^{-1} \mathrm{~g} \mathrm{~kg}^{-1}$ ), and wind fields in the section of the Baiu front detected in the analysis region between 1 and 7 July in c) the present-day climate and d) the future climate. 
tops of unstable layers are estimated at heights between $700 \mathrm{hPa}$ and $600 \mathrm{hPa}$ near $x=-200 \mathrm{~km}$. A well-developed low-level jet extends along the southern side of the front. These characteristics are consistent with the typical vertical structure of the Baiu front (Matsumoto et al. 1971; Akiyama 1973; Ninomiya 1984). In the future climate, mean $\theta_{e}$ near the surface increases from $356 \mathrm{~K}$ to $368 \mathrm{~K}$ on the southern side of the Baiu front axis (region-S), while the increase of $\theta_{e}$ at $500 \mathrm{hPa}$ is only $7 \mathrm{~K}$, from $340 \mathrm{~K}$ to $347 \mathrm{~K}$. This pattern of changes in $\theta_{e}$ indicates that the convective instability intensifies in the future climate. Tall structures of intense vertical vorticity (greater than $1.0 \times 10^{-5} \mathrm{~s}^{-1}$ ) are detected along the frontal zone, which is characterized by a large north-south gradient of $\theta_{e}$. Two characteristic jets associated with the Baiu front, a lowlevel jet (LLJ) located at $700 \mathrm{hPa}$ on the southern side (region-S) and an upper-level jet located at $200 \mathrm{hPa}$ on the northern side (region-N), are both projected to intensify in the future climate, from 6 to $7 \mathrm{~m} \mathrm{~s}^{-1}$ and from 22 to $24 \mathrm{~m} \mathrm{~s}^{-1}$, respectively. Intense mean updrafts that exceed $0.4 \mathrm{~cm} \mathrm{~s}^{-1}$, twice as large as those in the present-day climate, occur in the frontal zone near the intense vorticity centers (between $x=-200 \mathrm{~km}$ and $x=50 \mathrm{~km}$; not shown). Large amounts of rainwater and snow are found in these intense updrafts in the future climate (Fig. 11c and 11d). The amounts of rainwater exceed $0.5 \times 10^{-1} \mathrm{~g} \mathrm{~kg}^{-1}$, twice as large as those in the present-day climate. These results indicate that active moist convection in the frontal zone due to enhanced convective instability may contribute to the projected increase in the occurrence of intense daily precipitation.

These characteristics, the near-surface air mass with high $\theta_{e}$ over the sea south of the Japanese Islands and the intensifications of the two jets associated with the Baiu front, are well resolved by NHM-5km (Fig. 12). Figure 12 shows horizontal distributions of 25-year mean vertical vorticity at $500 \mathrm{hPa}$ and $\theta_{e}$ at $925 \mathrm{hPa}$. Wind speeds at $700 \mathrm{hPa}$ and $200 \mathrm{hPa}$ are overlaid in Fig. 12a and $12 \mathrm{~b}$, and wind speeds at $700 \mathrm{hPa}$ and horizontal wind shear exceeding $17 \times 10^{-6} \mathrm{~s}^{-1}$ at $500 \mathrm{hPa}$ are overlaid in Fig. 12c and 12d. In the future climate, an air mass with $\theta_{e}$ in excess of $355 \mathrm{~K}$ (about $10 \mathrm{~K}$ higher than in the present-day climate) persists at $925 \mathrm{hPa}$ over the sea south of Kyushu. This air mass is accompanied by intense southwesterly winds along the northwestern periphery of the westward-protruding subtropical anticyclone (Fig.
$12 \mathrm{c}$ and $12 \mathrm{~d})$. North-south gradients of $\theta_{e}$ in western Japan also increase in the future climate. A $700 \mathrm{hPa}$ jet extends over the sea south of Japan from the eastern coast of the Asian Continent to the Pacific side of the Japanese Islands. Regions of large wind shear (greater than $17 \times 10^{-6} \mathrm{~s}^{-1}$ ) can be identified along the northern edge of this jet. Intense positive vertical vorticity (greater than $1.5 \times 10^{-6} \mathrm{~s}^{-1}$ ) occurs over the sea northwest of Kyushu in the future climate (Fig. 12b), where a cyclonic circulation with relatively low-pressure prevails near the surface (Fig. 10d), and a pair of jets develops along the southern and northern sides of the Baiu front at $700 \mathrm{hPa}$ and $200 \mathrm{hPa}$, respectively. Similar characteristics have previously been identified as the atmospheric structures that bring large amounts of precipitation to the southwestern and western parts of Kyushu during the active phase of the Baiu front (Matsumoto et al. 1971; Ninomiya and Akiyama 1992). A number of previous studies have explored the effects of convective heating on the LLJ. Based on a modeling case study over Japan during the Baiu season, Nagata and Ogura (1991) reported that latent heating resulting from condensation produces a cyclonic circulation with low pressure, and that a LLJ appears on the southern side of this system. Kato (1998) studied the processes that maintain and enhance the associated LLJ using a numerical simulation of the stationary band-shaped torrential rain observed over southern Kyushu, and concluded that the pressure gradient force produced by convection-induced low pressure accelerates the mean horizontal velocity in the LLJ core. In this study, a cyclonic circulation with relatively low-pressure is identified on the northern side of the Baiu front, which is characterized by increases in the intensities of precipitation and convective activity in the future climate (Figs. $10 \mathrm{~d}$ and 11). These processes may contribute to the projected strengthening of the LLJ in the future climate, in turn supplying additional water vapor to the frontal zone.

The aforementioned characteristics are summarized in Fig. 13b, which shows the north-south distributions of north-south $\theta_{e}$ gradients, zonal and meridional winds, and specific humidity at a height of $500 \mathrm{~m}$, along with the amount of precipitation in the frontal zone. As above, these quantities are composited according to the location of the Baiu front axis. In the future climate, a large amount of precipitation occurs within a narrow region between $x=-400 \mathrm{~km}$ and $x=200 \mathrm{~km}$. The mean 

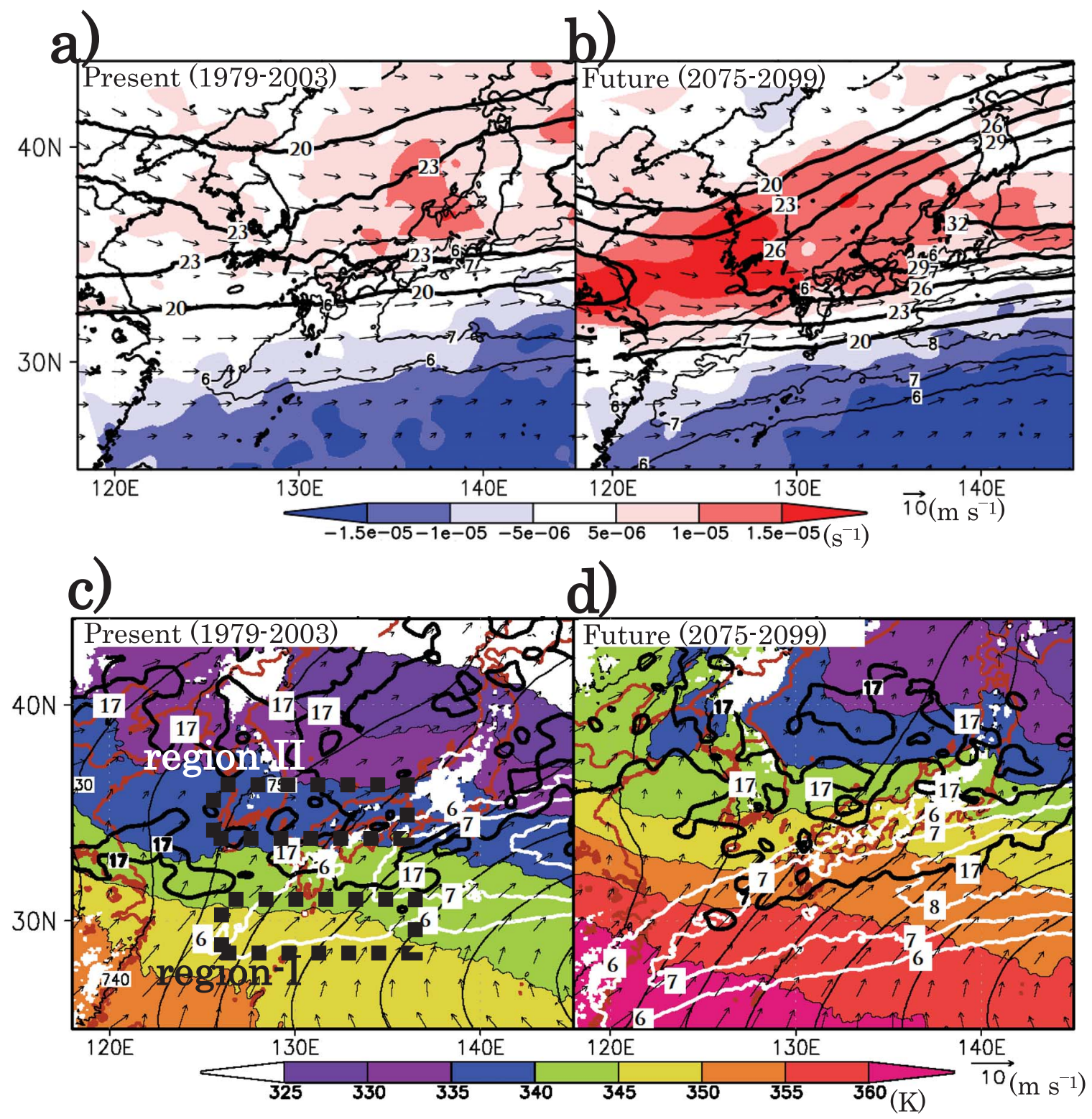

Fig. 12. Horizontal distributions of vertical vorticity (color: $\mathrm{s}^{-1}$ ) and wind fields at a height of $500 \mathrm{hPa}$, wind speeds at heights of $700 \mathrm{hPa}$ (thin contour: $\mathrm{m} \mathrm{s}^{-1}$ ) and $200 \mathrm{hPa}$ (thick contour: $\mathrm{m} \mathrm{s}^{-1}$ ) in a) the present-day climate and $\mathrm{b}$ ) the future climate. Horizontal distributions of equivalent potential temperature (color: $\mathrm{K}$ ) and wind fields at a height of $925 \mathrm{hPa}$, wind speeds at a height of $700 \mathrm{hPa}$ (white contour: $\mathrm{m} \mathrm{s}^{-1}$ ) and wind shear at a height of $500 \mathrm{hPa}$ (thick contour: $\mathrm{m} \mathrm{s}^{-1}$ ) in c) the present-day climate and d) the future climate. Data are averaged for days on which the Baiu front is located in the region $30^{\circ} \mathrm{N}-35^{\circ} \mathrm{N}$ and $125^{\circ} \mathrm{E}-$

$130^{\circ}$ E. Dashed rectangles in panel c) indicate analysis regions applied in Fig. 14.

intensity of the Baiu front (the north-south $\theta_{e}$ gradient) is approximately $-0.08 \mathrm{~K} \mathrm{~m}^{-1}$, about $0.01 \mathrm{~K} \mathrm{~m}^{-1}$ stronger than that in the present-day climate. Since near-surface increases of mean temperature from the present-day climate to future cli- mate in the vicinity of the Japanese Islands are larger on the northern side of $33^{\circ} \mathrm{N}$ than on the southern side, the near-surface north-south gradient of temperature is weaker in the future climate (not shown). The strengthening of the north- 


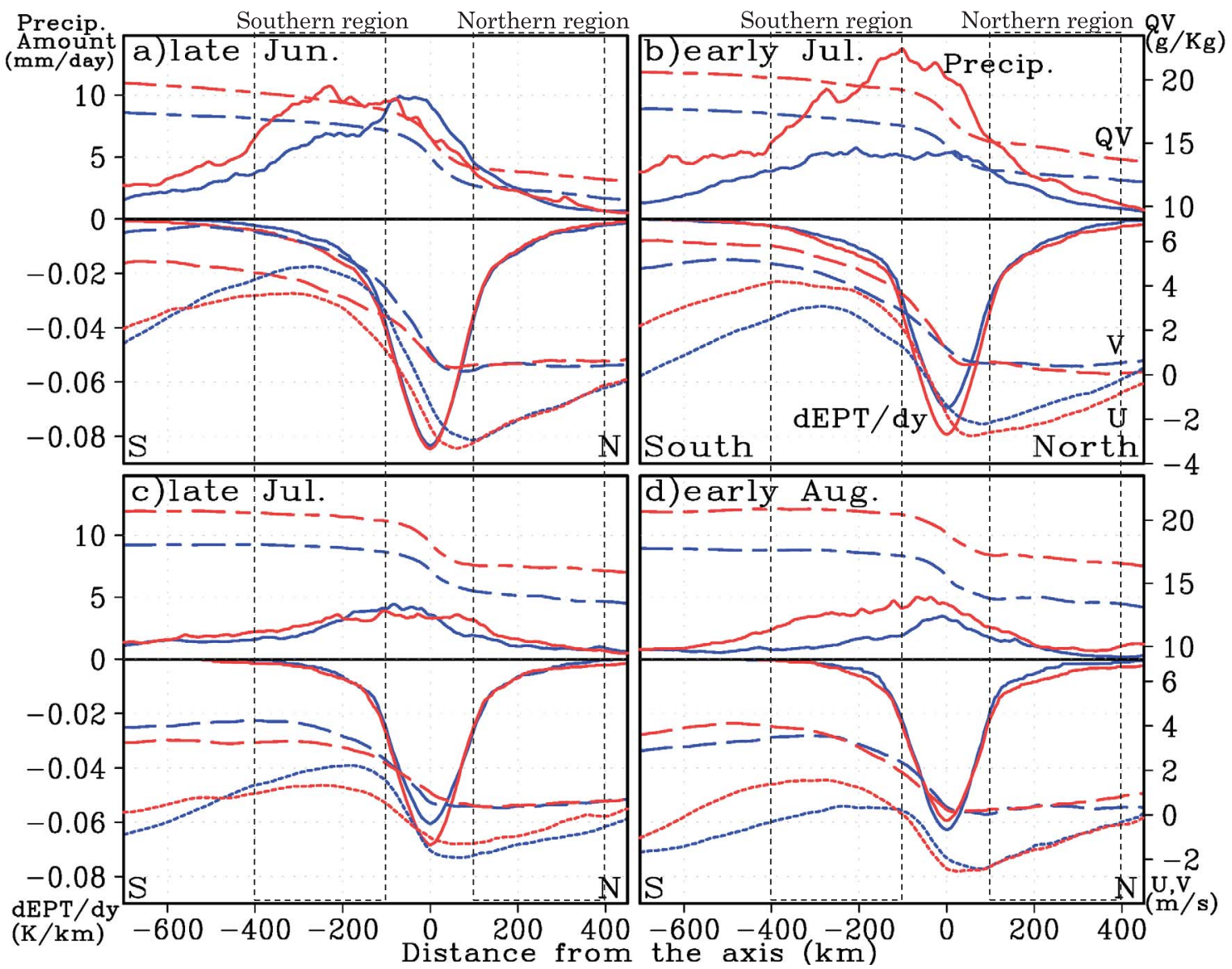

Fig. 13. Mean north-south distributions of the north-south gradient of equivalent potential temperature (dEPT/dy: solid line in lower panels: $\mathrm{K} \mathrm{km}^{-1}$ ), zonal wind (U: dotted line in lower panels: $\mathrm{m} \mathrm{s}^{-1}$ ), meridional wind (V: long dashed line in lower panels: $\mathrm{m} \mathrm{s}^{-1}$ ), specific humidity (QV: short and long dashed line in upper panels: $\mathrm{g} \mathrm{kg}^{-1}$ ) at a height of $500 \mathrm{~m}$, and precipitation amount (Precip.: solid line in upper panels: $\mathrm{mm} \mathrm{day}^{-1}$ ) around the Baiu front. a) 21-30 June, b) 1-10 July, c) 21-30 July, and d) 1-10 August. Blue and red lines denote the results of the present-day and future climate experiments, respectively. All data are composited with the Baiu front axis defined by the position of the largest north-south gradient of equivalent potential temperature at a height of $500 \mathrm{~m}$. Days for which typhoons are detected in the NHM$5 \mathrm{~km}$ model domain are excluded.

south $\theta_{e}$ gradient results from changes in water vapor. Mean values of water vapor in region-S $(x=-400 \mathrm{~km}$ to $x=-100 \mathrm{~km})$ increase from $16.9 \mathrm{~g} \mathrm{~kg}^{-1}$ in the present-day climate to $19.7 \mathrm{~g} \mathrm{~kg}^{-1}$ in the future climate. The statistical confidence for this projected increase in the mean water vapor exceeds the $99.9 \%$ confidence level. The difference between water vapor amounts in region- $\mathrm{N}(x=100 \mathrm{~km}$ to $400 \mathrm{~km})$ and those region-S increases from $4.4 \mathrm{~g} \mathrm{~kg}^{-1}$ in the presentday climate to $5.2 \mathrm{~g} \mathrm{~kg}^{-1}$ in the future climate, with statistical confidence above the $97 \%$ confidence level. Figure $13 \mathrm{~b}$ also shows that differences between the horizontal winds in region-S and those in region- $\mathrm{N}$ are projected to intensify in the future climate.

\section{Discussion}

\subsection{Comparisons between the mean structures of the front during the late Baiu season and during other periods}

To more fully examine the relationships between precipitation amounts, the intensity of the Baiu front, and environmental conditions, the 10-day mean north-south distributions in early July (Fig. $13 \mathrm{~b}$ ) are compared with those in other 10-day peri- 
ods during the Baiu season (Fig. 13a, 13c, and 13d). Late June and late July are selected to represent the peak and post-Baiu seasons. Another increase in climatological precipitation amount is found in the future climate during early August. Only data for which a Baiu front is detected between $30^{\circ} \mathrm{N}$ and $35^{\circ} \mathrm{N}$ are included in these 10-day composites.

In the future climate, the largest amount of precipitation associated with the Baiu front occurs in early July. Baiu precipitation during this period (defined as the mean amount of precipitation between $x=-400 \mathrm{~km}$ and $x=200 \mathrm{~km}$ relative to the Baiu front axis) exceeds $9.4 \mathrm{~mm} \mathrm{day}^{-1}$ in the future climate. In the present-day climate, the largest amount of precipitation $\left(6.2 \mathrm{~mm} \mathrm{day}^{-1}\right)$ occurs in late June. The mean intensity of the Baiu front (defined as the north-south $\theta_{e}$ gradient across the front) is strongest in June in both climates, and gradually weakens in July. Water vapor amounts over the sea south of the Baiu front axis increase during the Baiu period in both climates. By early July in the future climate, the mean intensity of the front is weaker than $-0.08 \mathrm{~K} \mathrm{~km}^{-1}$ but water vapor on the southern side of the Baiu front axis exceeds $19 \mathrm{~g} \mathrm{~kg}^{-1}$. A substantial amount of precipitation in excess of $9.4 \mathrm{~mm} \mathrm{day}^{-1}$ occurs during early July. The strongest zonal winds $\left(3.7 \mathrm{~m} \mathrm{~s}^{-1}\right)$ and the largest differences between zonal winds north and south of the Baiu front axis $\left(\sim 5.6 \mathrm{~m} \mathrm{~s}^{-1}\right)$ also occur during early July in the future climate. Although mean water vapor continues to increase during late July, the intensity of the front and the differences between winds north and south of the front axis both weaken. This weakening of the front in late July is accompanied by reductions in precipitation amounts in both climates. Precipitation amounts and the differences between winds north and south of the front axis both increase again in early August, even though the intensity of the front is weakest during this period.

Those features imply that an abundant supply of water vapor from the south, a large cross-front difference in horizontal winds which often accompany active fronts, and a steep north-south $\theta_{e}$ gradient are all essential for the occurrence of large amounts of precipitation in western Japan during the Baiu season. As shown in Fig. 13a and 13b, the most intense north-south $\theta_{e}$ gradient occurs during late June in both the present-day and future climates. In the future climate, however, the delay of the northward march of the Baiu front means that the front reaches western Japan in early July, when the environmental conditions are more humid than those in the present-day climate. As mentioned in Section 5, the Baiu front in the future climate is characterized by a smaller north-south gradient of near-surface temperature than that in the presentday climate throughout the entire analysis period (from mid-June to early August; not shown). Previous studies have pointed out that, while traditional fronts are characterized by large gradients of temperature and density, the Baiu front is characterized by large gradients of $\theta_{e}$ (Ninomiya 1984, 2000). It is interesting that the Baiu front in the future climate is characterized by a weaker gradient of temperature and a larger amount and stronger gradient of water vapor even than those in the present-day climate.

In the future climate, areas of intense positive vertical vorticity can be identified on the northern side of the Baiu front during early July (Fig. 12b). A large increase in precipitation amounts in western Japan is projected to occur during the same period (Fig. 10d). Ninomiya (2000) showed that the intrusion of mid-latitude disturbances into the Baiu frontal zone, which occurred in the vicinity of a cut off vortex, enhanced precipitation in the frontal zone by inducing both ascending motion and cold and dry advection. In this study, midlatitude disturbances can also be identified on the northwestern side of the Baiu front, over the area that extends from the northern part of the Asian Continent, across the Korean Peninsula to the northwestern part of western Japan (not shown). These disturbances may contribute to the projected increase of precipitation amounts in the future climate during early July. Further analysis of projected changes in these multi-scale disturbances will be required to adequately address this possibility.

\subsection{Changes in the environmental conditions around the Baiu front}

Figure 14 shows vertical profiles of mean temperature, specific humidity, relative humidity, and $\theta_{e}$ in early July averaged over the two regions defined by dashed rectangles in Fig. 12. Region-I and region-II are located south and north of Kyushu, respectively. In the future climate, a warming of approximately $2.3 \mathrm{~K}$ is projected at a height of $925 \mathrm{hPa}$ in both regions (Fig. 14c). The magnitude of the projected warming increases with altitude, reaching approximately $5 \mathrm{~K}$ at $250 \mathrm{hPa}$ in region-I and approximately $3.5 \mathrm{~K}$ at $250 \mathrm{hPa}$ in region-II. Because 


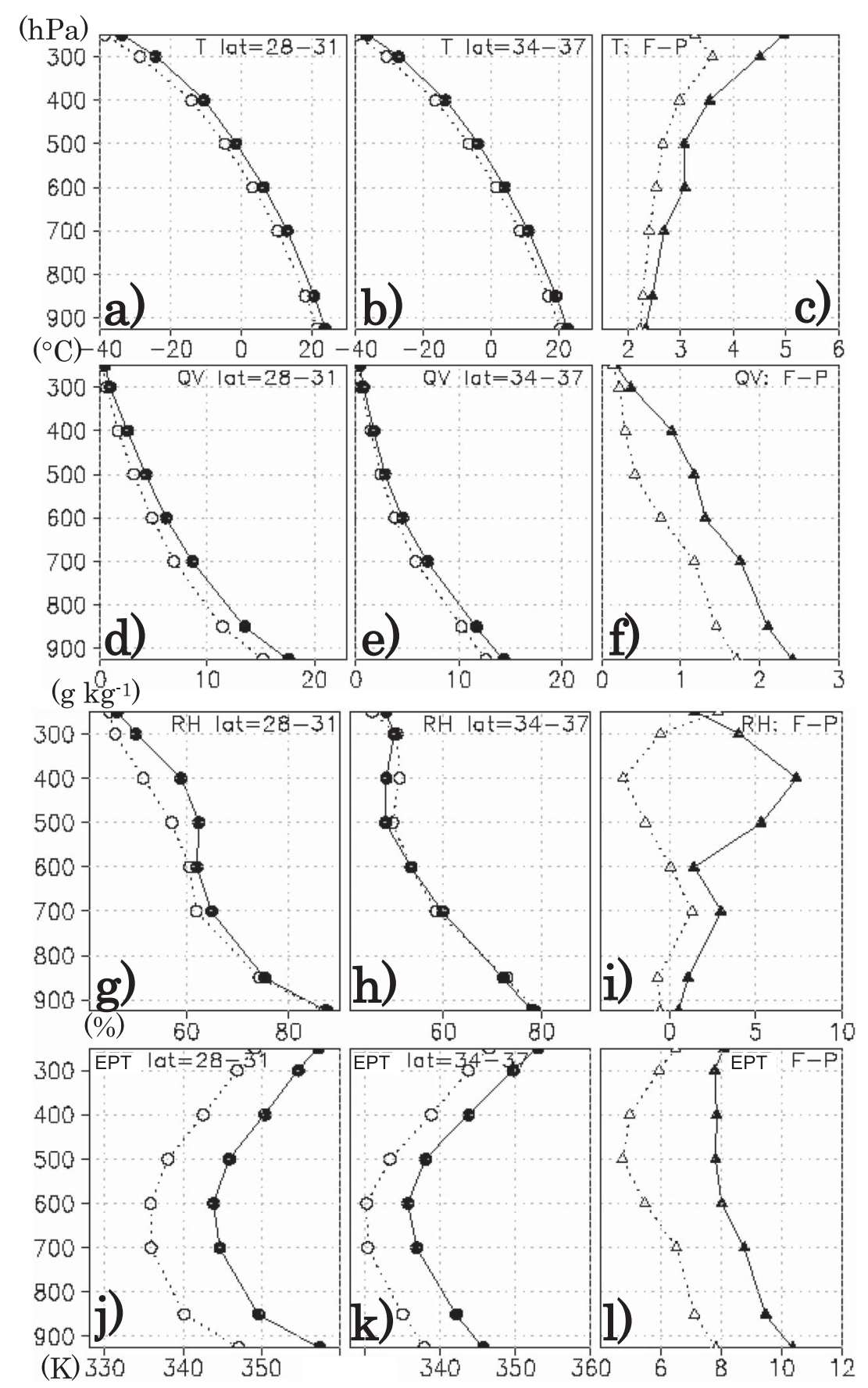

Fig. 14. Vertical profiles of temperature a) in region-I and b) in region-II for the regions defined in Fig. 12c. c) $[$ Future $]-[$ Present $]$ in both regions $\left({ }^{\circ} \mathrm{C}\right)$. Open-circle with dotted line, black-circle with solid line, blacktriangle with solid line, and open-triangle with dotted line indicate the present-day climate, future climate, [Future]-[Present] in region-I, and [Future]-[Present] in region-II, respectively. d), e), and f): Same as a), b), and c), but for specific humidity $\left.\left(\mathrm{g} \mathrm{kg}^{-1}\right) . \mathrm{g}\right), \mathrm{h}$ ), and i): Same as a), b), and c), but for relative humidity $(\%) . j), k)$, and l): Same as a), b), and c), but for equivalent potential temperature (K). 
of increasing sea surface temperature, substantial increases in specific humidity (approximately $2 \mathrm{~g} \mathrm{~kg}^{-1}$ ) occur at low levels in both regions (Fig. 14f). These increases in specific humidity are more pronounced in region-I, reaching $2.4 \mathrm{~g} \mathrm{~kg}^{-1}$ at $925 \mathrm{hPa}$, but become rapidly less pronounced with altitude in both regions. Relative humidity at low levels changes little between the present-day and future climates (Fig. 14i), because the increase in temperature approximately offsets the increase in specific humidity. The profile of relative humidity in region-I is suggestive of local deep convections that transport large amounts of water vapor upward to the middle level and above, while the middle level in region-II is drier. The low-level $\theta_{e}$ in region-I increases significantly (approximately $10.5 \mathrm{~K}$ ) in the future climate (Fig. 141). The increases in $\theta_{e}$ at middle levels are smaller than the increases at low levels in both regions. This discrepancy indicates that convective instability intensifies over western Japan, especially in region-II. The mean lifting condensation level (LCL) and level of free convection (LFC) in region-I in early July in the future climate are comparable with or slightly higher than those in the present-day climate (not shown); however, the mean convective available potential energy (CAPE) in the region-I increases from 1568 to $2070 \mathrm{~J} \mathrm{~kg}^{-1}$ between the present-day and future climates. The statistical confidence for this increase of CAPE exceeds the $99.9 \%$ confidence level. These results indicate that an air parcel lifted above the
LFC may experience moist convection of greater intensity in a more convectively unstable atmosphere.

\subsection{Comparison with results of ensemble experiments by AGCM60km}

The main features of the synoptic circulation in NHM-5km are inherited from output of the outer model, AGCM-20km. Like the NHM-5km, the AGCM-20km projects increases of precipitation amounts in early July and early August. In addition to the control experiments, three initial-value ensemble experiments are conducted using a $60-\mathrm{km}-$ mesh atmospheric global circulation model (MRIAGCM3.2H: TL319L64). The results of these ensemble experiments are used to further examine the projected increases in precipitation amounts over western Japan during the Baiu season.

Seasonal variations of daily precipitation over western Japan $\left(127^{\circ} \mathrm{E}-137^{\circ} \mathrm{E}, 30^{\circ} \mathrm{N}-35^{\circ} \mathrm{N}\right)$ are shown in Fig. 15, which is similar to Fig. 5a but shows MRI-AGCM3.2H results rather than NHM$5 \mathrm{~km}$ results. The ensemble-mean 25-year mean domain-averaged daily precipitation amounts are projected to increase significantly in early July in the future climate relative to the present-day climate. The statistical confidence for these increases in domain-average daily precipitation amounts exceeds the $95 \%$ confidence level. The increase of precipitation amounts in early August that has been identified in the AGCM-20km and NHM-5km

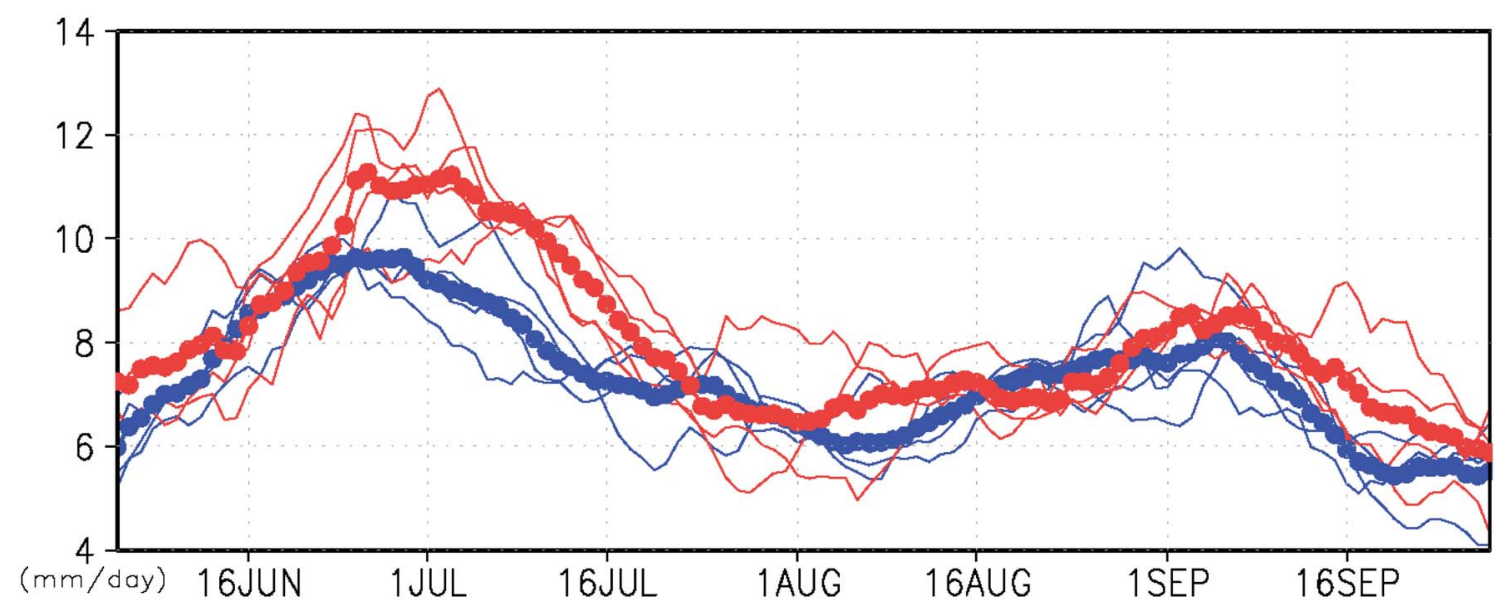

Fig. 15. Seasonal variations of 25 -year mean domain-averaged daily precipitation $\left(127^{\circ} \mathrm{E}-137^{\circ} \mathrm{E}, 30^{\circ} \mathrm{N}-\right.$ $35^{\circ} \mathrm{N}$ ) by 4 -member ensemble experiment using AGCM-60km to simulate the present-day (1979-2003, blue lines) and future (2075-2099, red lines) climates. All data represent 5-day moving averages. Blue and red circles indicate ensemble means for the present-day and future climate ensembles, respectively. 
results is not reproduced by the MRI-AGCM3.2H ensemble simulations.

The delay in the northward march of the Baiu front and the increase in precipitation amounts over western Japan in the late Baiu season are consistently projected for the future climate by both the ensemble simulations and the AGCM-20km. The NHM-5km results further reveal significant increases in the fraction of precipitation amount that occurs in intense precipitation (over $100 \mathrm{~mm} \mathrm{day}^{-1}$ ). These projected changes in precipitation amounts appear to be related to projected changes in the structure and characteristics of the Baiu frontal zone.

\section{Summary}

As part of the Kakushin Program, regional climate change experiments have been performed using a non-hydrostatic model with a horizontal resolution of $5 \mathrm{~km}$ (NHM-5km). These NHM$5 \mathrm{~km}$ simulations are used to project future changes in precipitation over Japan between June and October.

The present analysis projects a remarkable increase in precipitation amounts around western Japan in early July, which corresponds to the late Baiu season. The fraction of precipitation amount that occurs in intense daily precipitation (over $100 \mathrm{~mm} \mathrm{day}{ }^{-1}$ ) also increases significantly. In the present-day climate, $9.4 \%$ of precipitation amount in western Japan during early July occurs as intense precipitation that exceeds $100 \mathrm{~mm} \mathrm{day}^{-1}$. In the future climate, this value rises to $14.5 \%$.

Changes in the Baiu front between the presentday and future climate simulations are investigated. In the future climate, the northward march of the front is delayed relative to that in the present-day climate. The statistical confidence of the differences between the mean positions of the front during the late Baiu season (21 June to 10 July) in the future climate from those of the present-day climate exceeds the $90 \%$ confidence level. In the presentday climate, the mean intensity of the Baiu front weakens as it marches northward in July. In the future climate, this weakening is less pronounced. In early July, during the period when substantial increases in precipitation amounts are projected over western Japan, the mean location of the Baiu front is $33.5^{\circ} \mathrm{N}$ in the present-day climate and $33.0^{\circ} \mathrm{N}$ in the future climate. The simulated Baiu front is more intense over the sea west of western Japan $\left(30^{\circ} \mathrm{N}-35^{\circ} \mathrm{N}\right)$ in the future climate (north-south $\theta_{e}$ gradient of $\left.-0.08 \mathrm{~K} \mathrm{~km}^{-1}\right)$ than in the present-day climate $\left(-0.07 \mathrm{~K} \mathrm{~km}^{-1}\right)$.

Composite analyses of the front in early July according to front location reveal tall structures of intense vertical vorticity (greater than $1.0 \times 10^{-5} \mathrm{~s}^{-1}$ ) along an intensified frontal zone with more intense updrafts and larger amounts of rainwater in the future climate relative to the present-day climate. The two characteristic jets associated with the Baiu front, which are located at $700 \mathrm{hPa}$ on the southern side of the front and at $200 \mathrm{hPa}$ on the northern side, are projected to intensify in the future climate. Large increases are also projected with respect to both mean values and north-south gradients in $\theta_{e}$ and water vapor. The mean amount of water vapor on the southern side of the front at $500 \mathrm{~m}$ altitude is projected to increase to $19.7 \mathrm{~g} \mathrm{~kg}^{-1}$ in the future climate, $2.8 \mathrm{~g} \mathrm{~kg}^{-1}$ larger than that in the presentday climate. The convective instability over western Japan is projected to intensify in the future climate. Both the more abundant supply of water vapor and the intensification of convective activity under more convectively unstable environmental conditions may contribute to the projected increase in the occurrence of intense daily precipitation around western Japan during the late Baiu season.

These future increases in precipitation amounts over western Japan in early July are also projected by AGCM-20km (MRI-AGCM3.2S) and by a 3member ensemble experiment using AGCM-60km (MRI-AGCM3.2H). The models consistently project a future delay in the northward march of the Baiu front and a future increase in precipitation amounts around western Japan in the late Baiu season. The NHM-5km results further project a future increase in the fraction of precipitation amount that occurs in intense daily precipitation (greater than $100 \mathrm{~mm} \mathrm{day}{ }^{-1}$ ) during the late Baiu season with high statistical confidence. Because populations living in East Asia have been suffering from heavy rainfall events nearly every year, these projections of future increases in the occurrence of intense precipitation are both relevant and timely. These results are possible because NHM-5km is able to explicitly represent the cloud systems that cause intense precipitation.

To reveal the mechanisms behind the projected delay in the northward march of the Baiu front, further analysis of the large-scale circulation changes over East Asia should be carried out using the results of the AGCM- $20 \mathrm{~km}$ and AGCM- $60 \mathrm{~km}$ experiments. 


\section{Acknowledgments}

This study was supported by the Ministry of Education, Culture, Sports, Science and Technology of Japan under the framework of the "KAKUSHIN" program. Numerical simulations were performed using the Earth Simulator. The "KAKUSHIN-3" modeling group is gratefully acknowledged for carrying out the project. Mr. S. Hayashi and Mr. H. Tsuguti are thanked for their useful suggestions and discussions. The authors also acknowledge the referees and editor for their productive comments.

\section{References}

Akiyama, T., 1973: The large-scale aspects of the characteristics of the Baiu front. Paper Meteor. Geophy., 24, 157-188.

Akiyama, T., 1989: Large, synoptic and mesoscale variations of the Baiu front during July 1982. Part I: Cloud features. J. Meteor. Soc. Japan, 67, 57-81.

Biao, G., H. Yamada, K. K. Reddy, H. Uyeda, and Y. Fudeyoshi, 2004: An observational study of the development of a rainband on a Meiyu front causing heavy rainfall in the downstream region of the Yangtze River. J. Meteor. Soc. Japan, 82, 10951115.

Chen, C.-S., W.-C. Chen, and W.-K. Tao, 2004: Characteristics of heavy summer rainfall in southwestern Taiwan in relation to orographic effects. J. Meteor. Soc. Japan, 82, 1521-1543.

Easterling, D. R., G. A. Meehl, C. Parmesan, S. A. Changnon, T. R. Karl, and L. O. Mearns, 2000: Climate Extremes: Observations, modeling, and impacts. Science, 286, 2068-2074.

Hegerl, G. C., F. W. Zwies, P. A. Scott, and V. V. Kharin, 2004: Detectability of anthropogenic changes in annual temperature and precipitation extremes. J. Climate, 17, 3683-3700.

Huffman, G. J., R. F. Adler, M. Morrissey, D. T. Bolvin, S. Curtis, R. Joyce, B. McGavock, and J. Susskind, 2001: Global precipitation at one-degree daily resolution from multi-satellite observations. J. Hydrometeor., 2, 36-50.

Huffman, G. J., R. F. Adler, D. T. Bolvin, G. J. Gu, E. J. Nelkin, K. P. Bowman, Y. Hong, E. F. Stocker, and D. B. Wolff, 2007: The TRMM multisatellite precipitation analysis (TMPA): Quasi-global, multiyear, combined-sensor precipitation estimates at fine scales. J. Hydrometeor., 8, 38-55.

IPCC, 2007: Climate Change 2007: The Physical Science Basis. Contribution of Working Group I to the Forth Assessment Report of the Intergovernmental Panel on Climate Change, S. Solomon, D. Qin, M. Manning, Z. Chen, M. Marquis, K. B. Averyt, M.
Tignor and H. L. Miller, Eds., Cambridge University Press, Cambridge, United Kingdom and New York, NY, USA, 996 pp.

Kain, J. S., and J. M. Fritsch, 1990: A one-dimensional entraining/detraining plume model and its application in convective parameterization. J. Atmos. Sci., 47, 2784-2802.

Kamiguchi, K., O. Arakawa, A. Kitoh, A. Yatagai, A. Hamada, and N. Yasutomi, 2010: Development of APHRO_JP, the first Japanese high-resolution daily precipitation product for more than 100 years. Hydro. Res. Lett., 4, 60-64.

Kanada, S., M. Nakano, A. Hayashi, T. Kato, M. Nakamura, K. Kurihara, and A. Kitoh, 2008: Reproducibility of maximum daily precipitation amount over Japan by a high-resolution non-hydrostatic model. SOLA, 4, 105-108.

Kanada, S., M. Nakano, and T. Kato, 2010: Climatological characteristics of daily precipitation over Japan in the Kakushin regional climate experiments using a non-hydrostatic 5-km-mesh model: Comparison with an outer global 20-km-mesh atmospheric climate model. SOLA, 6, 117-120.

Kato, T., 1998: Numerical simulation of the band-shaped torrential rain observed over southern Kyushu, Japan on 1 August 1993. J. Meteor. Soc. Japan, 76, 97-128.

Kato, T., 2006: Structure of the band-shaped precipitation system inducing the heavy rainfall observed over northern Kyushu, Japan on 29 June 1999. J. Meteor. Soc. Japan, 84, 129-153.

Kato, T., Y. Yamada, and M. Nakano, 2010: Improvement of Kain-Fritsch convection parameterization scheme to suppress its false predictions of rainfall areas along coastal lines. CAS/JSC WGNE Research Activities in Atmospheric and Oceanic Modelling, 40, 4.07-4.08.

Kitoh, A., M. Hosaka, Y. Adachi, and K. Kamiguchi, 2005: Future projections of precipitation characteristics in East Asia simulated by the MRI CGCM2. Adv. Atmos. Sci., 22, 467-478.

Kitoh, A., T. Ose, K. Kurihara, S. Kusunoki, M. Sugi, and KAKUSHIN Team-3 Modeling Group, 2009: Projection of changes in future weather extremes using super-high-resolution global and regional atmospheric models in the KAKUSHIN Program: Results of preliminary experiments. Hydro. Res. Lett., 3, 49-53.

Kusunoki, S., R. Mizuta, and M. Matsueda, 2011: Future changes in the East Asian rain band projected by global atmospheric models with $20-\mathrm{km}$ and 60 km grid size. Clim. Dyn., accepted.

Matsumoto, S., K. Ninomiya, and S. Yoshizumi, 1971: Characteristics of the Baiu front with heavy rainfall. J. Meteor. Soc. Japan, 49, 267-281.

Mizuta, R., M. Matsueda, H. Endo, and S. Yukimoto, 
2011: Future change in extratropical cyclones associated with change in the upper troposphere. J. Climate, accepted.

Mizuta, R., H. Yoshimura, H. Murakami, M. Matsueda, H. Endo, T. Ose, K. Kamiguchi, M. Hosaka, M. Sugi, S. Yukimoto, S. Kusunoki, and A. Kitoh, 2012: Climate simulations using MRI-AGCM 3.2 with $20-\mathrm{km}$ grid. J. Meteor. Soc. Japan, 90A, 253258.

Murakami, M. 1990. Numerical modeling of dynamical and microphysical evolution of an isolated convective cloud-The 19 July 1981 CCOPE cloud. J. Meteor. Soc. Japan, 68, 107-128.

Nagata, M., and Y. Ogura, 1991: A modeling case study of interaction between heavy precipitation and a low-level jet over Japan in the Baiu season. Mon. Wea. Rev., 119, 1309-1336.

Nakamura, M., S. Kanada, Y. Wakazuki, C. Muroi, A. Hashimoto, T. Kato, A. Noda, M. Yoshizaki, and K. Yasunaga, 2008: Effects of global warming on heavy rainfall during the Baiu season projected by a cloud-system-resolving model. J. Disas. Res., 3, $15-24$.

Nakanishi, M., and H. Niino, 2004: An improved Mellor-Yamada level 3 model with condensation physics: Its design and verification. Bound.-Layer Meteor., 112, 1-31.

Ninomiya, K., 1984: Characteristics of Baiu front as a predominant subtropical front in the summer northern hemisphere. J. Meteor. Soc. Japan, 62, 880-894.

Ninomiya, K., 2000: Large- and Meso-a-scale characteristics of Meiyu/Baiu front associated with intense rainfall in 1-10 July 1991. J. Meteor. Soc. Japan, 78, 141-157.

Ninomiya, K., and T. Akiyama, 1992: Multi-scale features of Baiu, the summer monsoon over Japan and the East Asia. J. Meteor. Soc. Japan, 70, $467-$ 495.

Ninomiya, K., and H. Mizuno, 1987: Variation of Baiu precipitation over Japan in 1951-1980 and largescale characteristics of wet and dry Baiu. J. Meteor. Soc. Japan, 65, 115-127.

Onogi, K., J. Tsutsui, H. Koide, M. Sakamoto, S. Kobayashi, H. Hatsushika, T. Matsumoto, N. Yamazaki, H. Kamahori, K. Takahashi, S. Kadokura, K. Wada, K. Kato, R. Oyama, T. Ose, N. Man- noji, and R. Taira, 2007: The JRA-25 reanalysis. J. Meteor. Soc. Japan, 85, 369-432

Saito, K., J. Ishida, K. Aranami, T. Hara, T. Segawa, M. Narita, and Y. Honda, 2007: Nonhydrostatic atmospheric models and operational development at JMA. J. Meteor. Soc. Japan, 85B, 271-304.

Sasaki, H., K. Kurihara, I. Takayabu, and T. Uchiyama, 2008: Preliminary experiments of reproducing the present climate using the non-hydrostatic regional climate model. SOLA, 4, 25-28.

Semenov, V. A., and L. Bengtsson, 2002: Secular trends in daily precipitation characteristics: Greenhouse gas simulation with a coupled AOGCM. Clim. Dyn., 19, 123-140.

Shin, C.-S., and T.-Y. Lee, 2005: Development mechanisms for heavy rainfalls of 6-7 August 2002 over the middle of the Korean Peninsula. J. Meteor. Soc. Japan, 83, 683-709.

Shiogama, H., A. Hasegawa, T. Nozawa, and S. Emori, 2008: Changes in mean and extreme precipitation in near-term predictions up to the year 2030. SOLA, 4, 17-20.

Takahashi, N., 2010: Interannual variations in seasonal march of polar frontal zone around Japan. $A G U$ 2010 Fall Meeting. A33A-0094.

Trenberth, K. E., A. Dai, R. M. Rasmussen, and D. B. Parsons, 2003: The changing character of precipitation. Bull. Amer. Meteor. Soc., 84, 1205-1217.

Wakazuki, Y., S. Kanada, C. Muroi, A. Hashimoto, T. Kato, M. Nakamura, A. Noda, M. Yoshizaki, and K. Yasunaga, 2007: Regional climate projection experiments on the Baiu frontal activity around the Japan Islands using a non-hydrostatic cloudsystem-resolving model. J. Earth Simulator, 8, 1325.

Watterson, I. G., and M. R. Dix, 2003: Simulated changes due to global warming in daily precipitation means and extremes and their interpretation using the gamma distribution. J. Geophys. Res., 108, 4379, doi:10.1029/2002JD002928.

Yasunaga, K., H. Sasaki, Y. Wakazuki, T. Kato, C. Muroi, A. Hashimoto, S. Kanada, K. Kurihara, M. Yoshizaki, and Y. Sato, 2005: Performance of the long-term integrations of the Japan Meteorological Agency nonhydrostatic model with use of the spectral boundary coupling method. Wea. Forecasting, 20, 1061-1072. 